\title{
Toward Sustainable Governance: Strategic Analysis of the Smart City Seoul Portal in Korea
}

\author{
Yejin Yoo
}

Citation: Yoo, Y. Toward Sustainable Governance: Strategic Analysis of the Smart City Seoul Portal in Korea. Sustainability 2021, 13, 5886. https:// doi.org/10.3390/su13115886

Academic Editor: Manuel Pedro Rodríguez Bolívar

Received: 18 March 2021

Accepted: 17 May 2021

Published: 24 May 2021

Publisher's Note: MDPI stays neutral with regard to jurisdictional claims in published maps and institutional affiliations.

Copyright: (C) 2021 by the author. Licensee MDPI, Basel, Switzerland. This article is an open access article distributed under the terms and conditions of the Creative Commons Attribution (CC BY) license (https:/ / creativecommons.org/licenses/by/ $4.0 /)$.
Department of Smart Cities Research Center, Korea Institute of Civil Engineering and Building Technology, 283, Goyang-daero, Ilsanseo-gu, Goyang-si 10223, Gyeonggi-do, Korea; yyjin@kict.re.kr; Tel.: +82-31-955-0854

\begin{abstract}
Currently, the efforts of many cities around the world, including Seoul, are aimed at transforming themselves into smart cities under a governance vision. Thus, the purpose of this study is to propose a reinforcement plan for the 'Smart Seoul' portal to develop into a cooperative, participatory, and network governance. We select four representative smart city portals from Barcelona, Amsterdam, Columbus, and Singapore and evaluate their main features and roles. We sort the features analyzed in each portal based on certain governance strategies, employing their key features as part of our evaluation criteria model. These evaluation criteria are used to analyze the 'Smart Seoul' portal and create a strengthening plan. The plan comprises a set of actions intended to improve the portal's capabilities in terms of disclosure of information, the participation of stakeholders, and civil petition services. When this plan is implemented, the resulting optimal information disclosure through the 'Smart Seoul' portal will ensure the transparency of Seoul's administration and create an environment in which citizens can actively participate in solving urban problems and making decisions. In addition, the results of this study will be an important guideline for the design and operation of smart city portals, and the catalogs for key features are expected to be used to make smart city portal design regulations in the future.
\end{abstract}

Keywords: smart city; 'Smart Seoul' portal; network governance; disclosure of information; participation; civil petition services; evaluation criteria

\section{Introduction}

The Seoul Metropolitan Government has created a cooperative model in which businesses, experts, and citizens participate and has promoted a smart city platform construction project that can create public value through network governance [1,2]. From 2019, the smart city platform has added the ability to hold meetings, make decisions, and innovate communication skills at any time [2]. It is also expected that the smart city platform will solve urban problems (transportation, environment, energy, etc.) [3], communicate with citizens, and contribute to realizing public values. Although various sensors based on advanced ICT (information and communications technology) are installed in cities and colossal data are provided through the 'Smart Seoul' portal, there are still many shortcomings in demonstrating citizen participation and public value [2]. Smart city projects are being promoted for changes to the government organization, changes in the position of government, city improvement, social and economic value creation, and solving of urban sustainability problems [4-6]. In this respect, the smart city platform can play an important role in e-government (electronic government) information disclosure, administrative efficiency, transparency, citizen-centricity, citizen participation, and cooperation [7-10]. In addition, it is developing as a tool that can realize network governance through mutual communication and the creation of new public value by utilizing the network of the platform [11-18]. Network governance contributes to solving social problems in the traditional bureaucracy and realizing it as a coordination method that seeks cooperation and interaction among members [11,15-18]. Since the network is formed through the interaction 
of a wide range of stakeholders, it is an open operating system that can share opinions and suggest alternatives and has also appeared in the public domain of many countries around the world $[11,18]$. Examples of platform government implementation include " challenge.gov" in the USA, "canada.ca" in Canada, the "citizen scientist participation platform (Bürger schaffen Wissen)" in Germany, and "Government 3.0" in Korea [11,12,17,18]. As part of electronic government (e-government) administrations, these platforms emerged along with the rapid growth of internet and were recognized as supporting entirely digital functions for participants. Accordingly, various participatory innovation platforms have emerged for urban revitalization and public service innovation [19-22]. Anttiroiko [23] called the direction of smart city evolution 'Smart City $2.0^{\prime}$, which involves civic joint participation, and proposed the name 'City-as-a-Platform'. End users of such a service, such as governments, businesses, and citizens, use data, which drives decision-making. Furthermore, based on city data connected through a smart city, smart citizens solve city problems and participate in major decision-making processes. The goals of government administration in the past and present are the same, namely, to improve public service and achieve a better quality of life. The government administrations of smart cities are evolving to incorporate decision-making based on collective intelligence through platforms. The roles of these governments are changing from 'doing things' to 'enabling participation in civic innovation' [7,23-25]. To manage e-governments through innovative PPPs (public-private partnerships), various countries around the world are operating portals of smart city platform according to their vision and purpose. In other words, participation, cooperation, and decision-making through the portal can realize public value $[13,14,26]$. Following this trend, the Korean government recognized the importance of such a portal and planned to develop a portal to be distributed to local governments. In 2007, the country started developing a smart city portal as a government project, and in 2013 , it announced a Korean portal. The standard portal, which has been certified since 2018, has been distributed to local governments [27]. To create a PPP model in which businesses, experts, and citizens participate in the realization of a smart city, the Seoul Metropolitan Government has established a portal through which information can be exchanged with stakeholders [28].

Therefore, the purpose of this study is to analyze smart city portals in 4 cities around the world to create evaluation criteria and to compare and analyze Seoul portals to suggest ways to improve network governance. First, the roles of smart city portals in various cities around the world appear to be different depending on each city's vision and goals. European cities focus on civil participation and human centeredness, while Asian countries focus on increasing national competitiveness. Likewise, in the case of the United States, private companies based on new technologies are at the forefront of the economy [29-33]. Therefore, considering these characteristics, we select smart city portals of European, American and Asian. The selected smart cities are Barcelona and Amsterdam in Europe, Columbus in the USA, and Singapore in Asia. The four selected cities were evaluated as excellent examples of smart city business performance by several international evaluation agencies and received awards [32,34-45], it was judged that the portals operated by these cities could also find best practices in design and operation. Second, the characteristics analyzed in the world's four portals are classified based on the concept of network governance, and the evaluation criteria are determined after arranging the core characteristics that appear in common. The evaluation criteria were divided into information disclosure, participation and cooperation, and civil service. In other words, the main concern is how to provide information and realize public value through participation and cooperation [46]. Citizens should not be tools for operating cutting-edge ICT technologies but find ways to speak out and become citizen-centered cities [47-49]. In addition, in order to realize sustainable governance, government portals must have the capacity to realize public value and a structural configuration that can continuously re-establish [50]. Of course, the four city portals selected in this study also have advantages and disadvantages. Therefore, by analyzing the features of the Seoul portal, good functions are continuously developed, and 
the shortcomings refer to good examples of other city portals to find a development plan to become a sustainable portal. In addition, through literature research, it seeks ways to improve the important factors (innovation, sustainability, efficiency, citizen-centricity, etc.) of the smart city platform claimed by several authors [4-10]. These improvement measures will be significant implications for the function improvement of Seoul portals and other city portals that plan and operate network governance through portals.

\section{Literature Review}

\subsection{Governance}

Governance through the government platform is to create public value and build a sustainable city by communicating and cooperating with the government, business, and citizens $[3,5,6,11,12,17,18,26,51-54]$. The definition of governance is variously defined as collaborative governance, meta-governance, and network governance according to viewpoints $[16,26,51,55-57]$. The concept of governance has been classified and used in multiple ways by several scholars $[15,17,51,58]$. However, it has a common characteristic that it seeks a new administrative management method through communication and cooperation to solve common problems. Collaborative governance emphasizes collaboration between government agencies, corporations, and private organizations. Collaboration is a group of activities that are performed through the joint work of two or more agents that seek to achieve a common goal [56,59]. The concept of meta-governance deviates from the dichotomous logic of governance theory and is related to how governments are involved in promoting and guiding self-organized systems of governance $[16,57]$. Therefore, the role of the government is limited, as it must continue to function through a network configuration. Network governance is a type of coordination characterized by an organic or informal social system as opposed to bureaucratic structures with formal relations between them [17]. Network governance based on self-organizing and decentralized relationships based on interactions between citizens and governments has become an important concept in the implementation of platform government [20,52,60-63]. Network governance has three unique features. First, network governance structures have autonomous but interdependent actors. The driving force behind such a network is that not all its actors can solve a particular problem on their own; thus, realizing that they need each other is key [53]. Second, collaboration between the actors of such a network takes place within self-constructed structures. At first, there is no interaction when they get together, but as they begin to interact with each other, they develop structures that also gradually begin to interact with one another. Third, network governance features the ability to solve complex social problems. Actors gather around common interests and try to find solutions through joint coordination [26]. Therefore, merging the concepts of network and governance provides a definition of network governance, namely, "governing with and through networks" [51]. Despite the various definitions of governance as described above, the common point is to create public value by seeking an innovative new administrative management system through information sharing, innovation, interoperability, efficiency, communication, participation, and cooperation $[7-9,14,64,65]$. Governments should also change their relationship with government, citizens, non-state actors, and other arms of government through smart city governance [10]. In addition, they must play 'role of coordinator', 'role of funder', and 'role of regulator' [66]. Providing much information through intelligent ICT technologies and platforms can be a high-quality service that the government can provide to citizens. However, citizens should be the center, and the role of the government and citizens is essential to develop into Inclusive Cities, Resilient Cities, and Innovative-Cities [47,48,67]. In the decision-making process, roles and activities for power sharing are needed [68], access to information should be equal, and inclusive governance without the underprivileged [13].

\subsection{E-Government Portal}

The establishment of a governance platform is being proposed for smooth communication and information exchange between stakeholders through the Internet $[9,10,20,23,61,63,69,70]$. 
In order to share various information on the platform the portal acts as a gateway (information window) when users access the platform, and is being built with organic connection and user-friendly design $[20,23,61,63,69,70]$. The reason for the rapid rise of such portals is that it is necessary to provide services and information flexibly and quickly in accordance with the diverse needs of citizens [71], and smooth communication between stakeholders has become necessary as the network effect increases [20,23,72-76]. In addition, the use of digital technology can enable citizens to more easily express and propose their opinions, improve citizens' awareness of public matters and increase the acceptance of policy decisions [15,20,23,61,64,65,70,74,75,77]. For this reason, portals are regarded as one of the core strategies used in various fields, and plans to develop e-governments have been actively implemented in public domains beyond those of industry, management, and the economy. Through portals, it is feasible to equalize the relationship between a government and its citizens, facilitate communication, and increase the flexibility of, democracy of, and participation in network governance structures [11,17,23,28,53,70]. Accenture [20] stated that e-governments can connect people and promote the delivery of innovative public services by acting as an intermediary. This can provide positive effects in terms of making data available and enhancing the cohesion between participants and organizations [67]. Gorwa [22] said that it is important to increase the role and value of portals by actively utilizing ICTs such as social media and the Internet to enhance their effect. These portals induce the active participation of users and allow all participants to create added value by exchanging information or services that they want [23]. In addition, interacting on a network is a useful way to handle complex environments and is suitable to facilitate information disclosure and sharing and the provision of customized services $[11,12,78,79]$. Janssen et al. [80] also argued that a portal is a tool enabling an e-government to deliver added value to its stakeholders, and it is also a useful way to deal with complex environments composed of numerous interactions and networks. Likewise, he emphasized that policies can be adjusted in ways that citizens prefer, and information can be shared and services can be provided to citizens. Citizens' ability to freely express themselves and propose their opinions through a portal enables their active participation and cooperation in policy making. As a result, the ultimate goal of governance can be achieved through a portal $[12,15,62]$. The concept or function of an e-government is defined in various ways, and the types of e-governments include government 2.0, open government, and lean government [12,80,81]. O'Reilly [12] insisted on the existence of a government 2.0 that could induce the innovation of stakeholders as an open government by introducing ICTs into the public domain. The key to this type of government is to design policies with stakeholders by using the Internet to increase government planning capabilities and data openness and to encourage the true engagement of citizens. In addition, for e-governments to maintain their sustainability, it is necessary to create an environment in which citizens can actively participate in various activities and to establish a new system facilitating the straightforward collection and analysis of public information. An open government refers to the expansion of citizen participation by seamlessly transferring information to citizens or by opening up decision-making processes on policy issues [82]. In other words, an open government should take a practical and broad approach to issues by increasing the possibility of citizens' participation through a managerial interaction method using a portal $[9,81]$. Real public value can be realized only when citizens' active participation and transparency are increased. Many countries around the world are looking for alternative ways to solve problems by publicizing them on portals and obtaining ideas from people $[83,84]$. Lean governments aim to provide online services, open data, and participatory innovation and reduce the complexity in the public sector. This concept is based on the slogan 'Doing more with less'. In other words, according to the current trend toward small government, it is necessary for lean governments to empower people to effectively solve social problems and reduce administrative inefficiencies [80]. This means reducing the role of the government in the public sector and actively engaging the private sector. The government should play not only a steering role but also the role of a facilitator so that 
private interactions can work smoothly [85-87]. This means that governments should have the capacity to connect actors or enable cooperation, and they should not just play the role of attracting the private sector to the public sector [86,87]. Considering the above concept of governance and e-government portal, a smart city portal plays a role in realizing flexibility, connectivity, creativity, self-organization, people-centeredness, and data-based network governance $[7,8,10,54,88]$. Additionally, these portals are recognized as important factors that distinguish an ordinary city from a smart city. Smart governments have built platforms and portals to provide information, drive collaboration, and encourage citizen participation. Therefore, it is necessary to create public value by listening to the voices of citizens through the portal and working together for urban innovation [7-9,13,14,48,49,88,89].

\section{Methodology}

The key step in the methodology of this study is to establish the evaluation criteria necessary to evaluate the governance function and role of the Seoul Portal. There are currently no clear references for this. Therefore, in this study, through literature review, key words of governance and e-government portals were extracted and the characteristics of portals operated in various cities around the world were analyzed. Further, by integrating the key words of literature review and the key features of the portal, an evaluation criteria is established. Here, there is also a limit to the objective criteria for selecting a representative global smart city portal. Therefore, four portals were selected in consideration of the awards experience of international evaluation agencies and the characteristics of each continent. Currently, the operation and role of smart city portals in cities around the world differ according to smart city policies, but the vision of improving the quality of life of citizens through participation and cooperation has a common point [29-33]. The selected smart cities were Barcelona and Amsterdam in Europe, Columbus in the USA, and Singapore in Asia for the following reasons. Barcelona Digital city has handled a simple premise since its beginning "no smart city without smart citizens." Therefore, all the programs and policies aim to play a key role in developing smart cities. Thanks to this set of policies, in 2014, Barcelona won the "European Capital of Innovation Award" competition organized by the European Commission [32,34], ranking it as the best smart city in Europe and becoming a benchmark for other European cities that apply the lessons learned from the experiences developed in Barcelona. Moreover, Barcelona, together with Singapore, are two of the smartest cities, according to the "Understanding the Challenges and Opportunities of Smart Cities report", carried out by Philips Lighting and Smart Cites World, which covered 150 variables that influence urban planning in cities $[35,36]$. Amsterdam Smart City brings forward a new approach where science, education, government, business partners, and societal organizations work together to identify complex urban challenges and provide efficient solutions. The development and success of Amsterdam Smart City were reflected in its prize as "European Capital of Innovation Award" in 2016, a competition organized by the European Commission [32,36]. In 2017 Amsterdam won the "World Smart City Award for a circular economy" in the Smart City Expo World Congress 2017 [37], and was also awarded for the "Best Government Emerging Technologies" by the World Government Summit Awards [38]. Moreover, Amsterdam has been ranked as the third smartest city globally in the "IESE Cities in Motion Index" in 2019 [39]. Columbus city has a bold vision to be a community that provides beauty, prosperity, and health for all of its citizens [40,41]. In 2015 was awarded in the Intelligent Communities Forum as the first "Intelligent Community City", also was the second Large American City "City of the Future" proposed by the fDi Magazine [41]. Furthermore, in 2016, the U.S. Department of Transportation (USDOT) awarded USD 40 million to the City of Columbus, Ohio, as the winner of the "Smart City Challenge". With this funding, Columbus integrates innovative technologies, applications, and services to develop smart solutions to community-centered transportation problems [41]. The Singapore Smart Nation program seeks to build a smart city with high speed, pervasive, intelligent, and secure ICT infrastructures, which support all city systems in an integrated way [42]. The main difference from other smart 
cities is being a city-state, which means it is compact, efficient and fast in implementing new solutions, pilots and prototypes [42]. Singapore was also recognized as the second smart city in the years 2018-2019 and reached the first position in the "Top 50 smart cities worldwide" for the years 2020-2021, developed by the Eden Strategy Institute [43,44]. It has also been awarded first place in the "Smart City Index" 2019 and 2020, developed by the Institute for Management Development [45]. The four cities selected as described above were evaluated as exemplary cases of the smart city project performance by international evaluation. Therefore, in this study, it was determined that the governance vision and purpose would be well reflected in the portals operated by these cities.

In addition, after analyzing the characteristics of the selected four portals and extracting key features, evaluation criteria of three groups were determined based on the governance concept. After analyzing the "Smart Seoul" portal using the determined evaluation criteria, a sustainable improvement plan was presented (Figure 1). In addition, we proposed a reinforcement plan for the Seoul portal in consideration of important elements of governance that the smart city platform must have along with the evaluation criteria [5,7-9]. In other words, it evaluated the governance sustainability of the smart city portal. Therefore, in this study, considering that there are no standard evaluation criteria in the governance analysis of smart city portals, four city portals and Seoul portals were compared and analyzed, and mutually exemplary cases were selected and reinforcement plans were presented. It is judged as a limitation of research at the present stage, and if continuous research results are derived and accumulated in the future, it is judged that evaluation and improvement measures based on theoretical discourse will be made.

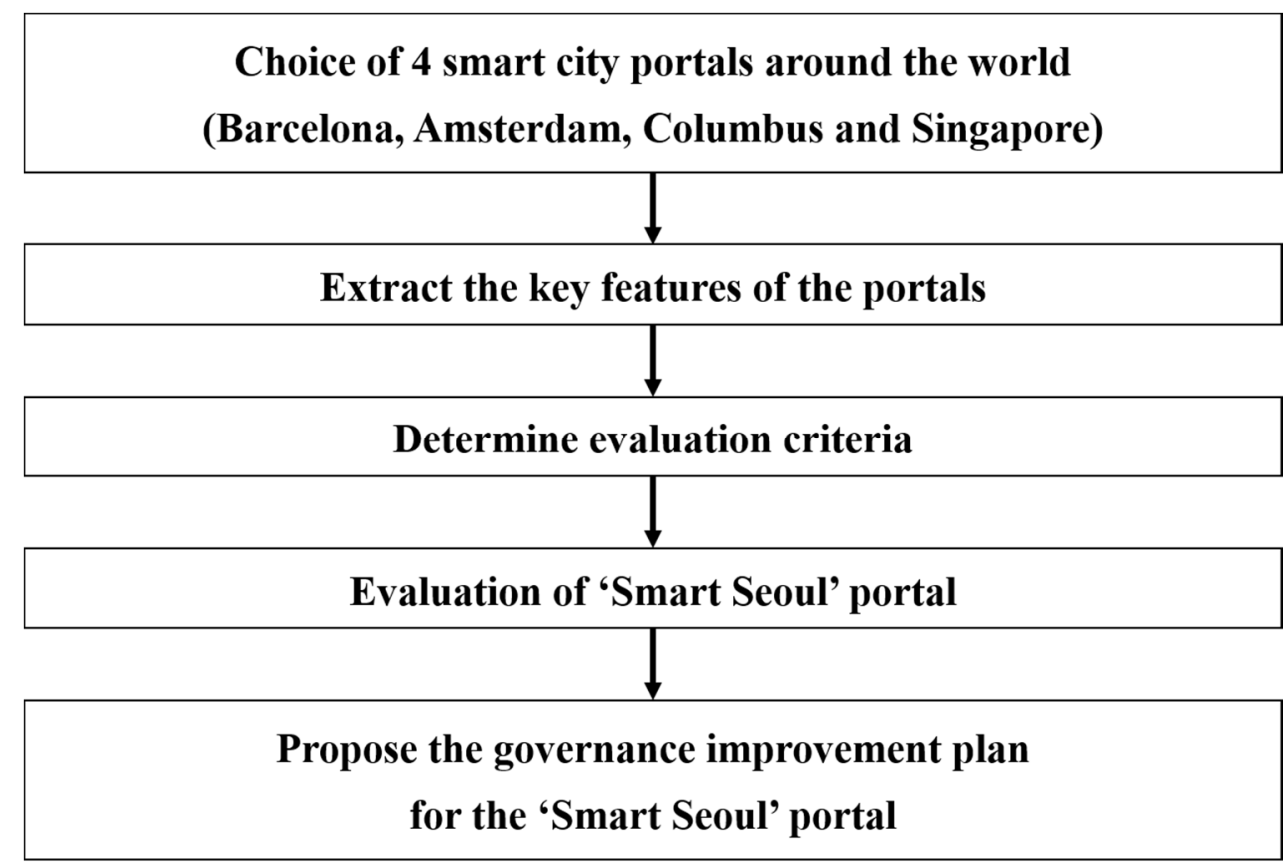

Figure 1. Flow chart of research method.

\section{Smart City Portal Analysis and Derivation of Evaluation Criteria \\ 4.1. Barcelona Digital City}

The 'Barcelona Digital City' portal [90] provides resources and information about transformation, innovation, and digital empowerment through the support of citizens [91]. The data collected from the city are shared with citizens and companies, promoting projects aimed at developing a smart city. The portal provides information about smart city projects. The projects are sorted by lines of action, and the objectives, activities, budget, expenses, and implementation time of each project are shown in detail for the benefit of the citizens. Various stakeholders participate actively due to the strategic governance model devel- 
oped by the Barcelona City Council to identify and involve them [34]. The Barcelona city council leads these smart city projects. Public agencies collaborate in their design and implementation. Private partners adapt their technology and finance investments to the projects. Entrepreneurs provide business ideas. Universities conduct research on smart cities. Citizens identify urban problems and comment on project proposals. In addition, to support the founding of businesses, the portal offers financial training, networking, and subsidy programs and supports entrepreneurs in their idea experimentation. Through technological events and joint work projects with other countries of the European Community, cooperation between entrepreneurs and international stakeholders who provide them with logistical support to start their businesses is encouraged. Furthermore, many projects are aimed at digital inclusion and training. Their priority axes are promoting creativity to foster technological vocations in children, actively training people in digital skills for future employment, and providing social, intergenerational, territorial, and gender inclusion training. Regarding information disclosure, in the 'Open Data $\mathrm{BCN}^{\prime}$, a total of 486 databases, 1981 historical series, and 2867 resources collected from public institutions are freely disseminated to citizens. The data are sorted into five groups: territory, population, city and services, administration, economy and business. The 'BCN Map' section provides the urban geographic information of the city. The BCN Guide provides citizens with information about cultural and leisure activities with location maps and advanced searches. The monthly statistics regarding data updates and publication, as well the support of the involved companies, are displayed. The statistics show an increasing trend in terms of new databases, historical series and search resources. The quality and accuracy of the databases is high, and there is an external agent in charge of their supervision. The data are searched with keywords, tags, formats, licenses, and geolocation, and the results can be downloaded in 38 formats, including GIS (geographic information system), text, web, and spreadsheet formats. Additionally, specialized users can create specific applications to link directly to the databases and search for customized information using the portal catalogs. For civil services, the 'Procedures' section provides tools to assist citizens in performing procedures, submitting complaints, searching queries and obtaining answers regarding administrative issues, and citizens can also request data within this section. Statistics show that the portal's capacity to serve users and solve complaints has been increasing monthly. The terms of use and data rights as well as the treatment of personal data and petitions are also provided in detail, guaranteeing individuals' privacy. Finally, the active participation of citizens in terms of contributing ideas and solutions to improve the portal's services and provide added value to various smart city projects is promoted through the 'BIT Habitat-l lab' program. There are challenges for programmer users to develop apps that facilitate data availability. The best work is awarded, and the apps are disseminated for the citizens' use. Based on the above comprehensive analysis, the general features of the Barcelona Digital City portal are summarized into a total of 13 categories: stakeholders' participation, information diversity, quickness, privacy and security, project collaboration, complaint processing, customized information, information up-to-date, information accuracy, education and training, start-ups and jobs, prizes and incentives, and international cooperation (Table 1).

Table 1. General features of the Barcelona Digital City portal.

\begin{tabular}{cl}
\hline Portal Name & \multicolumn{1}{c}{ General Features (13 Categories) } \\
\hline Barcelona Digital City & $\begin{array}{l}\text { Stakeholders' participation, information diversity, quickness, } \\
\text { privacy and security, project collaboration, complaint } \\
\text { processing, customized information, information up-to-date, } \\
\text { information accuracy, education and training, start-ups and } \\
\text { jobs, prizes and incentives, international cooperation. }\end{array}$ \\
\hline
\end{tabular}




\subsection{Amsterdam Smart City}

The 'Amsterdam Smart City' portal [92] collects information about smart city projects taking place in the metropolitan area of Amsterdam and facilitates expertise sharing by connecting citizens, innovative companies, knowledge institutions, and public agencies to create a city with a vision of the future. The portal is designed to show news, events, requirements, job opportunities, joint work experiences, and projects. There are 20 permanent partners working with the Municipality of Amsterdam on this portal, and 604 organizations are involved; most of them are actively participating and collaborating in the portal. Detailed contact information for the more than 8400 members, which include companies, knowledge institutions, public agencies, and citizens, as well as their contributed ideas, solutions, and smart city projects, are also provided. The projects are sorted into six channels: circular city, energy, mobility, citizens and living, digital city, and smart city academy. The objectives, activities, and stakeholders of each project are shown. For most of the projects, links to their specific web pages are provided. The portal shares the experiences and success stories of previous projects, participation information regarding ongoing projects and various expert comments. Events promoted by stakeholders to disseminate new technologies are also posted. Moreover, calls for citizens and entrepreneurs who wish to be part of various projects are published. A list of training courses for citizens is available in the 'Open Research Amsterdam' section of the portal. In the 'DataLab Amsterdam' section, free weekly demonstrations of the projects being managed by the Municipality of Amsterdam are held. Regarding information disclosure, the Municipality of Amsterdam has developed a 'Data and Information' portal that currently provides information from 320 databases, 20,864 data services, and 1248 publications. The databases are classified according to 12 topics: board, population, culture and recreation, sustainability and the environment, economy and tourism, education and science, public order and safety, space and topography, traffic, work and social security, living, care and welfare. The information can be searched with keywords, and the results can be obtained in various text formats, including spreadsheets, PDFs and GISs. There are application programming interface (API) services that allow specialized users to connect directly to the databases and obtain customized data. Additionally, the portal has a special 'interactive maps' section, which displays a variety of data in GIS web viewers according to spatial locations. There are no statistics on the precision of this data or the update frequencies. However, the last time the data were updated and the contact details of the staff in charge of updating the data services and ensuring the accuracy of the databases are shown. Since all members are free to upload information about projects, it is mentioned verbatim in the portal that the individuals who supply data are primarily responsible for its quality. Regarding civil services, the portal provides a personal space for each citizen, and they can log in to make requests about specific data that are not yet on the portal, report inconsistencies in the provided information and register complaints about the data services or the operation of the portal. The procedures for complaints are also detailed. Data privacy is guaranteed and regulated through standards transparently detailed on the portal. Based on the above comprehensive analysis, the general features of the Amsterdam Smart City portal are summarized into a total of 10 categories: stakeholders' participation, information diversity, privacy and security, project collaboration, complaint processing, customized information, up-to-date information, information accuracy, education and training, start-ups and jobs (Table 2).

Table 2. General features of the Amsterdam Smart City portal.

\begin{tabular}{cl}
\hline Portal Name & \multicolumn{1}{c}{ General Features (10 Categories) } \\
\hline Amsterdam Smart City & $\begin{array}{l}\text { Stakeholders' participation, information diversity, privacy } \\
\text { and security, project collaboration, complaint processing, } \\
\text { customized information, information up-to-date, information } \\
\text { accuracy, education and training, start-ups and jobs. }\end{array}$ \\
\hline
\end{tabular}




\subsection{Smart Columbus}

The main objective of the 'Smart Columbus' and 'Smart Columbus Operating System' portals [93] is to disseminate projects and data regarding smart transportation developed by the city of Columbus, which was awarded a budget of USD 50 million by the U.S. Department of Transportation's (USDOT) for this purpose. The 'Smart Columbus' portal details the current status of various smart transport projects and the involved collaborators and allows citizens to connect and become involved in the projects. Likewise, a second portal, namely, the 'Smart Columbus Operating System', provides data about the city for the development of smart city projects. These projects are headed by the Columbus City Council, Ohio State University, and the American Electric Power Company. The involved partners are private companies, foundations, universities, research centers, and technology businesses. After the project received a USD 50 million budget, several automotive and electric companies also joined as strategic partners to collaborate in project implementation. Projects are published with a high level of detail and can be filtered based on programs, leading organizations, types of technology, objectives, and spatial location. In addition, the 'Experience Center' is a physical area in which citizens can experience the use of new technologies related to transportation projects and receive training on these projects. There is also an 'Open Challenges' section that helps drive ideas on how open data can be leveraged to provide solutions to mobility problems. Specifically, regarding data disclosure, the 'Smart Columbus Operating System' provides services using more than 3000 databases classified according to six topics: mobility and transportation, parking, environment, energy, public health, and food access. The data can be searched with keywords and the names of data provider organizations, and the results can be displayed in various formats, including GIS. The data are also accessible through APIs. Users must log in to download the data, and some databases are restricted. The stakeholders of private companies are also invited to share their databases within the portal. There are no statistics on the quality of the data or the update frequency. However, the city of Columbus takes the necessary steps to provide reliable, up-to-date and high-quality data. The related metadata are also created under Project Open Data standards, and thus, their usefulness is guaranteed. Regarding civil services, citizens can contact the Columbus City Council and request data related to transportation that are not yet available on the portal. Moreover, they can report inconsistencies in the information received or register complaints about the data service or about the operation of the portal. On the portal, the Columbus City Council has shared a document called 'Data Management Plan' [41], which provides operational information on the privacy of personal data and the use of the available data. Based on the above comprehensive analysis, the general features of the 'Smart Columbus' portal are summarized into a total of nine categories: stakeholders' participation, information diversity, privacy and security, project collaboration, complaint processing, customized information, up-to-date information, information accuracy, education and training (Table 3).

Table 3. General features of the Smart Columbus portal.

\begin{tabular}{cl}
\hline Portal Name & \multicolumn{1}{c}{ General Features (9 Categories) } \\
\hline Smart Columbus & $\begin{array}{l}\text { Stakeholders' participation, information diversity, privacy } \\
\text { and security, project collaboration, complaint processing, } \\
\text { customized information, up-to-date information, information } \\
\text { accuracy, education and training. }\end{array}$ \\
\hline
\end{tabular}

\subsection{Smart Nation Singapore}

Singapore's "Smart Nation" portal [94] takes a national approach and encourages the use of new and innovative digital technologies for the development of the country, thus promoting suitable sustainability and habitability. The portal provides information on the country's economic activities and smart city projects. Since 'Smart Nation Singapore' is a portal promoted by the Government of Singapore, all public institutions are involved 
and collaborate towards the same purpose. Likewise, allied private companies are also part of the portal. The projects are sorted into six groups: strategic national projects, urban living, transportation, health, digital government services, start-ups and businesses. The development of research with the support of universities and research centers is included. Moreover, the portal offers financing programs and business accreditations as well as support and personalized advice for starting and growing small businesses, constructing capabilities, and internationalizing existing businesses. An innovation laboratory equipped with technological tools where the advice of experts can be obtained is also provided, in which start-ups or entrepreneurs with an idea can experiment and develop solutions. Citizens can test new digital products that are still under development, provide instant feedback and become familiar with new technologies. There is a repository of online learning resources for training citizens that is especially organized for elderly people, children, people with disabilities, entrepreneurs, working adults, and technology specialists who are interested in learning more about IT. Scholarship programs are also promoted for young Singaporeans to pursue studies in information technology. There are job opportunities aimed at professionals and experts, where the government offers temporary contracts for the development of new technologies that improve the quality of life of citizens. Applicants can propose ideas or join current strategic projects. Specifically, regarding information disclosure, the portal serves as a repository of more than 1880 datasets captured by the public sector, and they are displayed to citizens in a relevant and understandable way through visualizations and data narratives. The databases are sorted into nine subjects related to urban development, the economy, education, the environment, finance, health, infrastructure, society, technology, and transportation. There are tools to search for specific information using filters or based on a given provider agency, format, or topic of interest. In addition, citizens can explore the data through previews before downloading them. Specialist users can develop apps connected to the databases through APIs to obtain customized data in real time. Most of the datasets indicate that updates occur on a monthly, quarterly, or semiannual basis. In addition, the principles that are followed in the portal for data sharing are as follows: the data shall be made easily accessible, available for co-creation, released in a timely manner, shared in a machine-readable format, and be as raw as possible to ensure its accuracy. Regarding civil services, citizens can request data that are not yet available on the portal. They can also suggest changes to the data formats and submit complaints about errors. Citizens can also report problems regarding the unauthorized collection, dissemination, use, copying, or modification of personal, business, restricted, and government data. The protection of personal data and the privacy of the services offered through the portal are guaranteed. The portal offers incentives to citizens when facing challenges such as changing their mode of transportation, reducing the use of their vehicles and walking more. Furthermore, there is a program that aims to bridge the digital divide by providing low-income households with two years of subsidized fiber broadband connectivity and a tablet. Citizens who meet a set of requirements can participate. Based on the above comprehensive analysis, the general features of the 'Smart Nation Singapore' portal are summarized into a total of 11 categories: stakeholders' participation, information diversity, privacy and security, project collaboration, complaint processing, customized information, up-to-date information, information accuracy, education and training, start-ups and jobs, and prizes and incentives (Table 4).

Table 4. General features of the 'Smart Nation Singapore' portal.

\begin{tabular}{cl}
\hline Portal Name & \multicolumn{1}{c}{ General Features (11 Categories) } \\
\hline Smart Nation Singapore & $\begin{array}{l}\text { Stakeholders' participation, information diversity, privacy } \\
\text { and security, project collaboration, complaint processing, } \\
\text { customized information, up-to-date information, information } \\
\text { accuracy, education and training, start-ups and jobs, prizes } \\
\text { and incentives. }\end{array}$ \\
\hline
\end{tabular}




\subsection{Derivation of Evaluation Criteria}

After the features of the four smart city portals were analyzed, 13 general features were finally extracted: stakeholders' participation, information diversity, quickness, privacy and security, project collaboration, complaint processing, customized information, information up-to-date, information accuracy, education and training, start-ups and jobs, prizes and incentives, and international cooperation. Then, as shown in Figure 2, those with similar characteristics are combined into one among the general features. In other words, project collaboration, and international cooperation were combined into collaboration, complaint processing and service speed were combined into complaint processing, and a total of 11 key features were organized. In addition, 11 key features were classified into three groups, focusing on information disclosure [11-13,20,35,39-42,46,60-63], citizen participation $[28,46-49,60-63]$, and civil petition service $[13,46-49,52,60-63,67]$, which are the key keywords most importantly emphasized in the literature review on governance and government portals. Three key feature groups were defined as evaluation criteria for analyzing the 'Smart Seoul' portal. The disclosure group is information diversity, customized information, information up-to-date, and information accuracy. The participation group is stakeholders' participation, collaboration (international cooperation), education and training, and start-ups and jobs, and the civil petition service group is complaint processing (quickness), privacy and security, and prizes and incentives (Figure 2). As a result, by comparing and analyzing the characteristics of the Seoul portal and the other four portals, it was conducted to enable an objective evaluation of the characteristics of the "Smart Seoul" portal, and find a way to achieve more advanced and sustainable network governance.

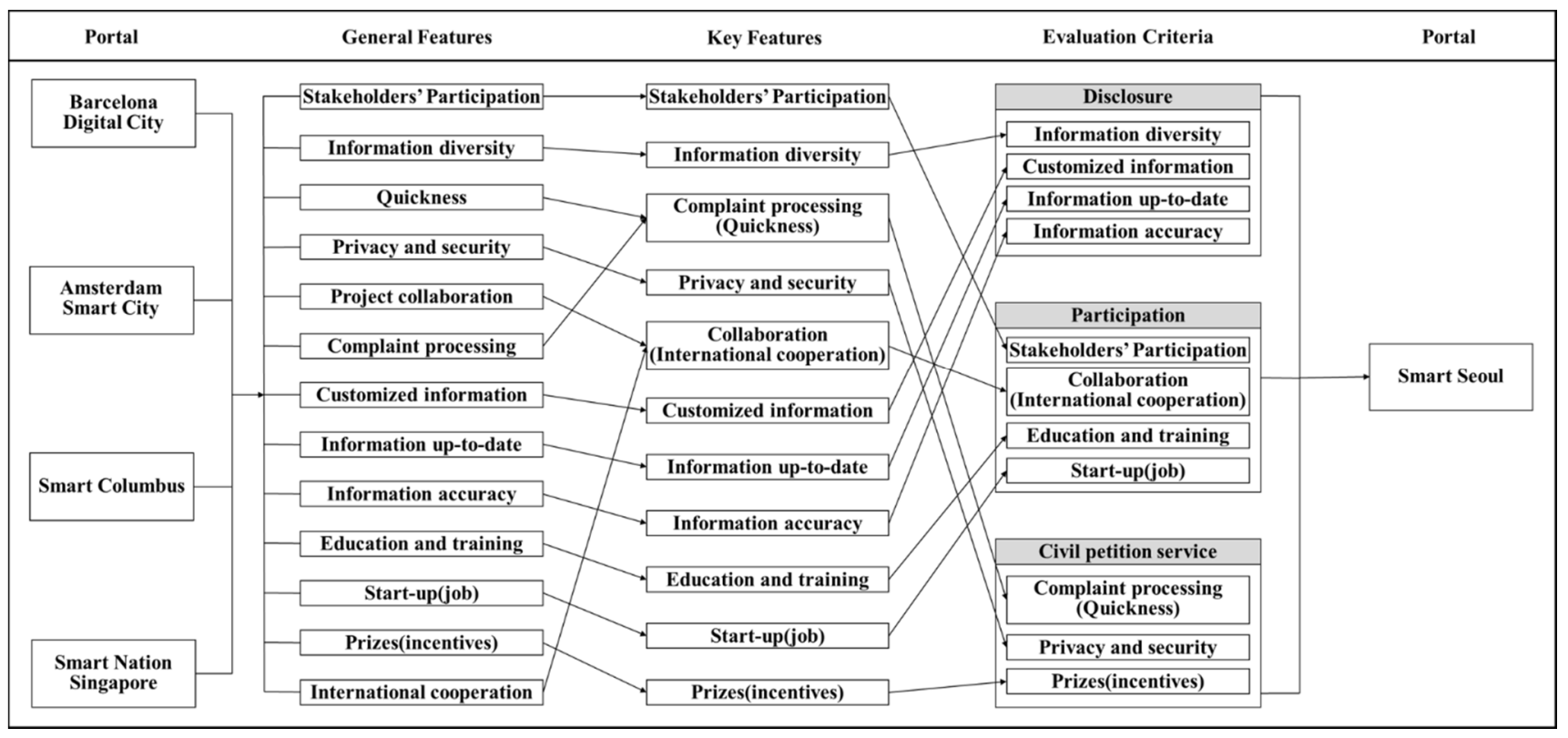

Figure 2. Derivation of key features and evaluation criteria.

\section{Evaluation of Smart Seoul Portal}

\subsection{Overview}

Seoul longs for a fair society in which all citizens can express themselves, make suggestions, and have an equal voice. For this reason, a plan has been developed for the construction of a smart city model and a platform that integrates technologies allowing citizens to connect and directly understand the dynamics of the city $[95,96]$. In 2012, the Seoul Metropolitan Government launched the 'Open Data Plaza' portal, which provides information on various urban issues to the citizens of Seoul and maintains a line of communication with them. In 2013, the city of Seoul adopted the results of public data research, integrating the information from its various offices into a large data platform. Each de- 
partment provided the required data and participated in content planning to complete the baseline work [2]. In August 2016, the initial smart city platform model was created. The 'Smart Seoul' portal [97] was implemented, and the Seoul Digital Foundation is currently managing it. This portal also integrates the 'Open Data Plaza' portal as part of its platform. The 'Smart Seoul' portal is designed to collect and disseminate information of interest to citizens and companies according to eight basic categories of urban development in the city: traffic, safety, the environment, welfare, the economy, housing, culture, and administration. Figure 3 is the Homepage of 'Smart City Seoul Portal'.

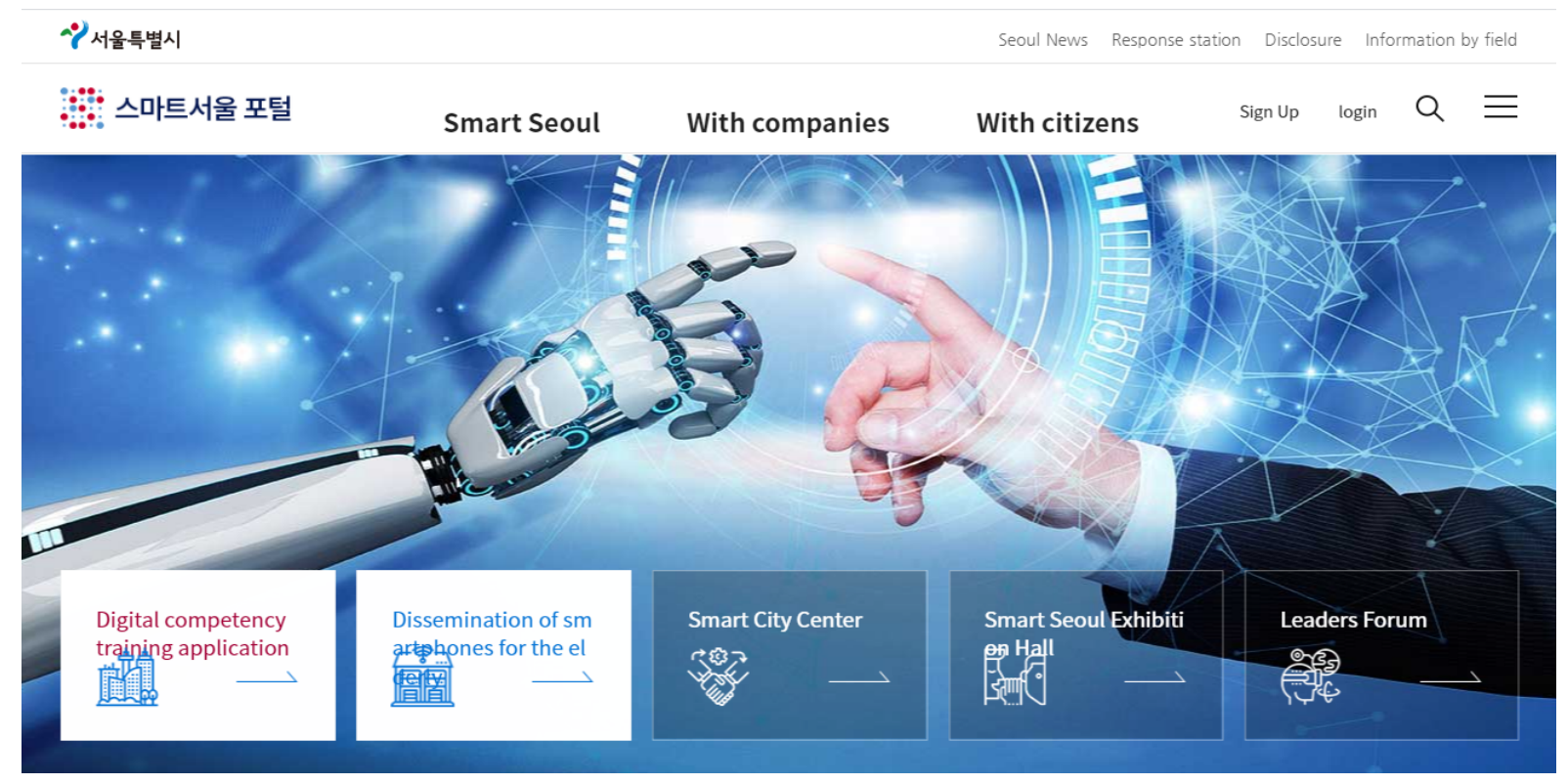

Figure 3. Homepage of 'Smart City Seoul Portal' [97].

The vision of this portal is based on five components: smart services to citizens, management and dissemination of data, cooperation between public and private institutions, sustainable technological innovation, and advanced technology for a smart city ecosystem. The portal provides information in thematic sections clearly organized and oriented to support different groups of stakeholders, disseminate different types of data and respond to user petitions. A description of the portal menu is detailed in Table 5.

The content of the three main axes of the 'Smart Seoul' portal are explained below: First, 'Smart Seoul' axis is aimed at explaining the objectives and scope of the technological development in the city of Seoul, enabling it to be at the forefront of smart city development. In this regard, the Seoul Metropolitan Government details its activities, policies, cooperation, and events, and provides links to web portals that show the progress of other smart cities around the world. The related content is classified into five sections: Vision and Strategy, Major Business, Global Cooperation, Reference Room, and News. Second, 'Companies' axis is related to promoting the participation of stakeholders in the development of smart city projects and providing technological facilities and logistical support for the experimentation of ideas and solutions. The related content is classified into four sections: Smart City Center, Corporate Solution Zone, Enterprise Support, and Corporate Voice. Third, 'Citizens' axis focuses on efforts to promote the active participation of citizens in becoming familiar with the new technologies that are being implemented in smart city projects in Seoul. To achieve this, the portal provides a series of facilities related to education and the training of citizens. It also links to the 'Open Data Plaza' data search portal and provides an explanation of its usage procedures. The content is classified into five sections: Smart Citizen Lab, Smart Seoul Exhibition Hall, Open Data, Digital Competency Enhancement Education, and Education Resources. In addition, the portal is connected through a hyperlinked menu to sections related to news, solutions to 
civil petitions, the dissemination of data, and information sorted by subjects. To conduct a governance evaluation of the 'Smart Seoul' portal, the three criteria of the evaluation model are considered (disclosure, participation, and civil petition service) and described in the following sections.

Table 5. Main axes and hyperlinked menu contents.

\begin{tabular}{|c|c|}
\hline Menu & Content \\
\hline Axis: Smart Seoul & $\begin{array}{l}\text { Provides information on the activities performed by the Seoul Metropolitan Government for the } \\
\text { development of smart city projects, vision, strategies, international cooperation and related events. }\end{array}$ \\
\hline Axis: Companies & $\begin{array}{l}\text { Shows information about the facilities and support provided by the Seoul Metropolitan Government to } \\
\text { companies and entrepreneurs where they can register and test technological development ideas oriented } \\
\text { towards smart cities }\end{array}$ \\
\hline Axis: Citizens & $\begin{array}{l}\text { Displays information about the training facilities and events that the Seoul Metropolitan Government } \\
\text { provides to their citizens to teach them about the scope of digital and technological advancement in } \\
\text { smart cities. It also provides links and the procedures to obtain data from the 'Open Data Plaza' portal. }\end{array}$ \\
\hline Seoul News & $\begin{array}{l}\text { Shows information about the activities and events held by Seoul Metropolitan Government and external } \\
\text { institutions to promote projects in smart cities and other areas. It also has links to pages with informative } \\
\text { material on the main activities that take place in Seoul. }\end{array}$ \\
\hline Response Station & $\begin{array}{l}\text { Provides all the necessary information to address civil petitions, complaints and reports from citizens } \\
\text { about problems in the city, the corruption of officials, problems regarding administrative practices, etc. }\end{array}$ \\
\hline Disclosure & $\begin{array}{l}\text { Provides the administrative procedures for obtaining official information from the Seoul Metropolitan } \\
\text { Government. This section is linked to the 'open.go.kr' portal in which a citizen can register and } \\
\text { download information from the public sector; it is sorted according to } 12 \text { areas of interest (health, the } \\
\text { economy, education, regulatory reform, welfare, safety, leisure, nurseries, jobs, housing, administrative } \\
\text { finance, and the environment). }\end{array}$ \\
\hline Field Information & $\begin{array}{l}\text { Displays a list of links to external pages that provide detailed information about the eight urban } \\
\text { development subjects considered essential by the Seoul Metropolitan Government, namely, traffic, safety, } \\
\text { the environment, welfare, the economy, housing, culture, and administration. }\end{array}$ \\
\hline
\end{tabular}

\subsection{Disclosure}

Through the portal, the open city is managed through communication, openness, participation and exchanges. The portal also uses big data, mobile information, spatial information, and the cloud in accordance with the changing ICT environment to provide various tailored services to citizens. From this perspective, information disclosure is an important evaluation factor in the context of strengthening governance. Specifically, for this evaluation, the 'Disclosure' and 'Field Information' sections and the 'Open Data Plaza' portal are especially important. In the 'Disclosure' section, the processes and policies for obtaining public information from administrative agencies are detailed. This service has facilitated more than 21 million searches so far and provides information collected from various public institutions and sorted according to its function, purpose and scope, including data on small and medium industries, general public administration, agriculture, forestry, fisheries, education, welfare, science and technology, defense, culture, sports, tourism, public order and security, communication, transportation, diplomacy, health, environmental protection, and local development. In addition, there are 1200 CCTV (closed-circuit television) information installed throughout Seoul, Integrated Safety Situation Room (over 300 million raw data), 120 Dasan Call Center, and various civil petitions [2]. The administrative information, which is fully disclosed in the portal and current as of October 2020, comprises 20,346,504 approval documents, 9313 policy and research data points, 24,414 financial data points, and 2951 important questions and meetings. Through this portal, citizens can also obtain information on all the coordination meetings, decision-making processes, reports, notifications, activities, and results of the Seoul Metropolitan Government and its various committees, which are sorted according to the following issues: transportation and construction, women and family, the environment, 
health, cultural tourism, finance and taxes, housing and urban planning, the economy, welfare, security, and administration. Custom information can be searched according to scope, year, type of disclosure, producing agency, Seoul-area location, approval level, and whether attached details are included. Statistics on the status of information disclosure requests, the number of services performed, and the types of services provided can also be viewed on the portal. These statistics are updated monthly and show that over $95 \%$ of the information available to the public had been disclosed in 2020. There are also statistics about the information that is most often requested by citizens, information requests for business purposes, information disclosures of public interest, and regulations on the use of specialized information. This section is also linked to the national portal called 'Information Disclosure', which is managed by the Ministry of Public Administration and Security of Korea. In this portal, citizens can log in and request information using search methods that employ keywords and data types. The information is provided at the national level and sorted by subject.

The 'Field Information' section is a service space of the Seoul Metropolitan Government that provides information on eight subjects of urban development: traffic, safety, the environment, welfare, the economy, housing, culture, and administration. Each of them is linked to a specialized web page that provides more detailed information on each subject. This information can also be sorted in alphabetical order. One of the most valuable and well-used services of this portal is the 'Open Data Plaza', which is linked through the 'Citizens' axis. The 'Open Data Plaza' portal provides public data to the citizens of Seoul. The portal provides a total of 6654 databases, 13,721 types of services, and 5072 open APIs. The portal classifies this information into twelve groups: general administration, city management, the environment, safety, education, industry and the economy, welfare, traffic, culture and tourism, health, population, and housing. The data can be obtained through searches using tags, popular search terms, and file types that include word processing, spreadsheet, GIS, open API and graphical formats. Developer users can link the databases through a LOD (linked open data) service, in which they can connect and directly obtain, process, and display or download customized data on attached web pages. The Seoul Metropolitan Government promotes the maintenance of the portal and the continuous updating of the data provided there. Statistics on the available data, which are sorted by subject, the agency that provides them, the related administrative area of the city, and the gender of the provider, are shown. These data are free for all registered citizens, but copyright restrictions apply based on intended usage.

\subsection{Participation}

Stakeholders are essential for the dynamic and interactive operation of smart city portals. They are important in the implementation of programs and projects and the contribution of relevant ideas and solutions for the benefit of urban development. Considering the advantages of Korea's ICT, the Seoul Metropolitan Government strives to clearly define the mission of smart city development and strategically identify and communicate with its stakeholders. The Seoul Metropolitan Government leads smart city projects, coordinates strategic alliances with private companies and government agencies for the implementation of these projects and supports the development of ideas promoted by entrepreneurs or small companies. Public agencies cooperate in the design, monitoring, and implementation of smart city projects based on their fields of competence. The involved private partners are strategic allies of the Seoul Metropolitan Government; they collaborate in the execution of ideas and smart city solutions and adapt their technological products to the requirements of the projects so that they can be used in the implementation phase of these developments. Companies and businesses participate in smart city projects and recruit entrepreneurs to finance ideas and solutions that provide business benefits and encourage urban development. Entrepreneurs can provide business ideas within the smart city framework, and the Seoul Metropolitan Government supports them and evaluates their effectiveness for subsequent implementation. Knowledge institutions and universities 
conduct research and participate in the development of pilot projects in smart cities; they also perform educational activities. Citizens make suggestions regarding projects, attend events and receive training on new technologies in smart cities. The portal can connect the Seoul Metropolitan Government with its stakeholders in many ways. The three main axes, namely, 'Smart Seoul', 'Companies', and 'Citizens', are focused on the promotion of projects and communication with stakeholders. Within the 'Smart Seoul' axis, the sections 'Major Business' and 'Global Cooperation' report on smart city projects that the Seoul Metropolitan Government is leading and projects being done in collaboration with other cities worldwide. The 'Major Business' section provides a description of the main projects that the Seoul Metropolitan Government is currently implementing. The projects for urban development are sorted according to six themes: transportation, safety, the environment, welfare, the economy, and administration. Each project has a web page that provides a brief introduction to the project as well as its objectives, business information, benefits, and implementation schedule, and it shows the milestones that have already been reached and those that have been planned for the following years. The 'Global Cooperation' section describes the collaborative efforts between the Seoul Metropolitan Government and international organizations to achieve smart city objectives. The development plan of the project and the results achieved by WeGO (World Smart Sustainable Cities Organization) are also described there. This organization seeks to improve people's quality of life, innovate in the context of the provision of public services, and strengthen regional competitiveness. The Seoul Metropolitan Government currently chairs this organization and is an active member along with more than 200 cities, businesses, and institutions worldwide.

Within the 'Companies' axis, there are different alternatives for working with businesses that wish to develop or be a part of the technological projects in the smart city. The Seoul Metropolitan Government makes the 'Smart City Center' available to them, which is a physical space with several technological tools intended to be used as an experimental environment for the creation of businesses. In addition to this technological equipment, the advice of expert staff, who guide the activities in the center, support the management and connectivity of the databases, and distribute plans in the market, is also provided. Another option for interaction with stakeholders is detailed in the 'Corporate Solution Zone' section, where companies subscribed as corporate members in the portal can register the ownership of their smart city technological solutions. After being approved, the solutions can be marketed in the promotion channel of the portal, included in smart city projects, integrated into alliances with public institutions or acquired by citizens or other companies. Furthermore, the 'Enterprise Support Business' section offers opportunities to recruit entrepreneurs and companies to participate in the development of technological solutions for smart city projects. Through the 'Citizens' axis, the Seoul Metropolitan Government also promotes various ways to help citizens understand new technologies linked to smart cities. In the 'Smart Citizen Lab' section, options are offered to recruit citizens individually or in groups so that they can participate in finding solutions to the urban problems in Seoul according to their technical competence. In addition, citizens can be integrated into evaluation teams for new technology product alternatives and participate in tutoring programs. The portal also lists events in which private companies explain the trends and current developments of technologies intended to provide services related to smart cities. Likewise, the development of forums on which to share policies and collect companies' and citizens' opinions regarding problems and solutions in cities are promoted. In the section 'Smart Seoul Exhibition Hall', the procedures for citizens to register and visit the Smart Seoul Pavilion, where they can learn about the operation of the computer infrastructure used for the collection and use of public data as well as the cooperation activities and businesses led by the Seoul Metropolitan Government, are detailed. In the 'Citizens' axis, the registration process for and use of the 'Big Data Campus' service is explained. This service is open to all citizens, universities, research organizations, public institutions and private entrepreneurs, and its objective is to provide a physical space with technological resources for the management of big data. The large volumes of data available through 
the 'Open Data Plaza' portal can be used in the campus to develop research projects or propose technological ideas related to smart cities. The technology-related training and dissemination activities intended to increase the knowledge of citizens are grouped in the section 'Digital Competency Enhancement Education'. Citizens can register and access several online education computer resources, workshops, etc., which are grouped by topics related to smart cities, and can review the history of their visits and training that they have received. This section offers face-to-face and online courses and addresses specific queries about the use of digital equipment. Seoul seeks to be an inclusive smart city without digital alienation. There is even a special section of the portal dedicated to providing education on the use of digital devices to the elderly. Moreover, in the 'Education Resources' section, basic educational content about the use of new technologies such as smartphones, cell phone internet use, messaging apps, and Wi-Fi connections is disseminated online. Citizens have a space to practice uploading data obtained from the 'Open Data Plaza' portal and can view them in the format of statistical reports and personalized graphics that they can edit. The purpose of this is to achieve participatory governance that includes citizens in the technological development of cities.

\subsection{Civil Petition Service}

The civil petition service is a well-developed space of the Seoul Metropolitan Government that guarantees transparent, collaborative and effective governance in the context of addressing complaints and requests from citizens. In the hyperlinked Menu of the portal, there is a shortcut to the page 'Response Station'. This portal outlines the entire process of addressing civil petitions. Citizens can submit applications detailing their requests and complaints about the administrative services provided by the Seoul Metropolitan Government. They can also comment on urban problems that require quick solutions and that are of common interest. In addition, they have the option of filing complaints about corruption cases in public organizations, project financing, problems involving human rights violations, breaches of obligations in neighborhoods, and the abuses of neighbors, and they can request information such as the detailed calculation of local taxes. There are also multiple ways to submit complaints and petitions, which can be done in person or through the portal, a mobile app, text messages, phone calls, or letters sent using postal services. After a citizen logs into the relevant page and makes a petition or complaint request through the 'Application' menu, the Seoul Metropolitan Government refers the issue to the corresponding area of government, which publishes its response under the 'Case Collection' menu option. Responses regarding petitions of general interest can be viewed by all citizens. Petitions that are not within the scope of work of the Seoul Metropolitan Government are referred to the corresponding public institutions. According to the statistics shown on the page, citizens use the page regularly and present petitions constantly, and this activity has gradually increased during the last 3 years. In 2019, the number of cases exceeded 2,300,000. The requests made through this system are related to the subjects of traffic $(62 \%)$, the environment and safety $(21 \%)$, housing and construction $(6 \%)$, welfare, culture and the economy (3\%), and other topics (8\%). Furthermore, in the 'Education Resources' section of the 'Citizens' axis, there is a 'Citizens Voice' subsection, where the Seoul Metropolitan Government collects opinions and suggestions from citizens on projects related to smart cities through surveys, competitions, and contests. Likewise, this section provides a window of interaction with citizens, where requests for specific information that has not yet been considered in the portal and that is of public interest can be submitted. After a citizen submits a request for new information, this request is visible to other citizens so that they can agree to the need for such data. The management of information on personal data, petitions, complaints, and data requests, as well as the permissions and the rights of use of the information received from the portal is also detailed, guaranteeing individuals' privacy and security. 


\section{Implications and Strengthening Plan}

The 'Smart Seoul' portal aims to cover all the aspects of smart cities, provide a network governance solution to address the information needs of citizens and other stakeholders, and maintain interaction with them. The main goals of the portal are participation, communication, cooperation, and urban problem solving in Seoul; to achieve this, the portal promotes, disseminates and provides facilities for the development of ideas, solutions and projects in several different ways. It also has a wide selection of trainings and virtual education promoting the inclusive participation of society. Likewise, it provides links to specific pages that provide information, allow for the resolution of complaints and civil petitions, and detail transparent security policies related to the use of data. However, the portal will be able to continue to progress and fully meet its objectives only when its vision and development strategy are integrated with the experiences gained, opinions developed, and lessons learned during the operation period. Therefore, based on the analysis of the three criteria considered in the evaluation model, the following actions for improvement are proposed to strengthen the governance development strategies of smart city portals.

\subsection{Disclosure}

From the analysis of the subjects related to disclosure, it can be clearly understood that these sections of the portal are well organized within specific web pages launched when the Smart Seoul portal was established. The 'Open Data Plaza' and 'Disclosure' portals already had supporting hardware, software, and web development infrastructure. Strategically, the 'Smart Seoul' portal takes advantage of the hardware infrastructure of the 'Open Data Plaza' portal as part of its requirements [97]. The 'Smart Seoul' portal is currently linked to both portals, and it employs them as specialized external tools for the use of citizens and other stakeholders when seeking information $[95,96]$. To achieve governance strategies related to the disclosure of information, the 'Open Data Plaza' portal provides thousands of databases and specific data services hosted by the Seoul Metropolitan Government $[2,97]$. These data are well organized and can be accessed through various search functions that deliver results in specific formats. Many of them are even provided in open API formats and can be linked as services on other web pages. Furthermore, the 'Disclosure' portal is also of great interest to citizens, since more than 21 million information requests were presented and addressed. However, there is a function that has not yet been fully realized in either portal, namely, there are no GIS tools to search data or GIS viewers available to display results. In the 'Open Data Plaza' portal, there are few result formats that include JSON (JavaScript object notation) or that include geolocation formats enabling users to display results in GIS viewers. Likewise, the 'Disclosure' portal is full of menus and predefined options that show hundreds of results. Additionally, there are few filtering tools, and GIS viewer environments have not been considered. Although not all the data displayed in the portal have spatial connotations, many of them are statistics related to Seoul that, for better visualization and analysis, can be drawn spatially in accordance with administrative divisions, points of interest, or areas delimited by coordinates or linked to existing landmarks within a geographic space. For example, the 'Barcelona Digital City' provides a GIS viewer in its 'BCN Map' that shows the urban geographic information of the city, including the locations of the main services and facilities, traffic monitoring data, and addresses and street names [34,90]. Likewise, the 'Amsterdam Smart City', has an 'Interactive Maps' section, where citizens can search for information with spatial connotations through a link to its 'Data and Information' portal [92]. In addition, most of the data from both portals are accessible as GIS downloads and can be displayed directly in map viewers. For this reason, a proposed action is the expansion of the 'Open Data Plaza' and 'Disclosure' portal services to implement web GIS viewers that can offer an easier alternative for data searching and disclosure based on geographic locations of interest to citizens or stakeholders. The GIS viewer should integrate the search methods that are already operating in the 'Open Data Plaza' portal, such as those utilizing keywords and tags. The design environment of the 'Disclosure' portal could thus provide user-friendly 
searching and access to information with more filters to obtain specific data and with GIS viewers that identify more facilities through searches based on geolocation. Likewise, GIS formatted data must be included in the utilized statistical data to enable geographic visualization and analyses of the spatial distribution of sets of results through GIS viewers. This action allows the network governance strategies regarding data accessibility to be enhanced by offering citizen-friendly portals enabling data searches and disclosure. In addition, as an open government portal, it should be able to improve the usefulness and visibility of public data to create citizen-centered, transparent, and sustainable public interests $[5,9,46,64,65,88,89]$.

A second point to mention about the 'Open Data Plaza' and 'Disclosure' portals is that the strategy used to organize the available information according to categories of interest and offer search alternatives that provide benefits to citizens has been very successful [97]. However, searches on these portals usually provide hundreds of results, so citizens must perform the additional activity of determining which of them is closest to what is desired. For this reason, there is always the risk that a user may feel overwhelmed due to the amount of information provided. The 'Open Data Plaza' portal has a section in which the inquiries of citizens are collected; since 2012, more than 1750 cases have accumulated [97]. However, most of these cases are related to inquiries about required data and service errors (downloads, incomplete data, delay in data delivery, etc.). There are very few cases where users could be motivated to give suggestions on how to improve the portal's search functions. The 'Amsterdam Smart City' has a special 'Feedback' menu in its 'Data and Information' portal that encourages users to suggest improvements in the services of the portal and in the way that it provides data [92]. Likewise, both the 'Amsterdam Smart City' and 'Smart Nation Singapore' periodically send surveys to their registered users to measure their level of satisfaction with the services offered on their portals [92,94]. Therefore, a proposed action is to obtain feedback through specific surveys from registered citizens on their level of satisfaction with the design and utility of the search tools and methods of both portals [88]. After analyzing these surveys, a plan should be enacted to improve the facilities and data searching methods of the portals, following the governance strategy on easy, friendly, and flexible data disclosure to citizens $[7-9,54,76,89]$. There is also a specific section that facilitates interactions with citizens, which may require the addition of information of public interest that is not yet possible to obtain from the portal. In addition, to secure the openness of information disclosure, it is necessary to find a way to secure the quality of data by directly uploading information generated by citizens or companies to the portal and displaying producers [48]. In other words, through the optimization and communication of smart technology, direct and two-sided links are established between government and citizen services, and authority and responsibility are shared [7-10,54,68]. In the case of 'Barcelona Digital City', the Barcelona City Council provides education programs for citizens belonging to associations and civic groups to disclose information related to smart cities and new technologies [2,95-97]. Therefore, this proposed action serves to further promote the training activities of citizens organized in associations or social groups, enabling a proper understanding of the role of the technologies and services that can be provided through the framework of smart cities $[7,25,54,68]$. Through this action, the strategy of participatory governance can be strengthened, and more citizens can use the portal while knowing its full potential and understanding its cooperative governance; in this way, citizens can suggest the creation of new databases that will serve to satisfy common needs. However, even if the portal discloses much high-quality information, it is meaningless to disclose the information if citizens do not understand the public information and do not know how to use it. This means that information disclosure should also be citizen-centered [46-48]. In order to enable citizens to use information dynamically, a plan should also be sought to disclose information usage through portals. Democracy can be strengthened through information sharing by providing public services through portals so that citizens can use information dynamically $[76,88,89]$. The strengthening plans for the above information disclosure are summarized and shown in Table 6. 
Table 6. Strengthening plan for disclosure.

\begin{tabular}{|c|c|c|}
\hline Proposed Action & Reference Portal & References \\
\hline $\begin{array}{l}\text { Providing GIS viewer and search function } \\
\text { (facilities, civil service, address, street name, } \\
\text { etc.): Data search, providing results in GIS } \\
\text { format, GIS filtering, etc. }\end{array}$ & $\begin{array}{l}\text { Smart Seoul portal: 'Open Data Plaza', } \\
\text { 'Disclosure' } \\
\text { Barcelona Digital City: 'BCN Map' }\end{array}$ & {$[5,9,34,46,64,65,88-90]$} \\
\hline $\begin{array}{l}\text { Information search through interactive map } \\
\text { window, download in GIS data for-mat, and } \\
\text { GIS visualization of spatial distribution }\end{array}$ & $\begin{array}{l}\text { Smart Seoul portal: 'Open Data Plaza', } \\
\text { 'Disclosure' } \\
\text { Amsterdam Smart City: 'Interactive Maps', } \\
\text { 'Data and Information' }\end{array}$ & {$[5,9,46,64,65,88,89,92]$} \\
\hline $\begin{array}{l}\text { Regular service satisfaction survey to } \\
\text { registered users: Searching for information } \\
\text { provision methods that can satisfy users } \\
\text { through feedback, provision of information } \\
\text { according to classification system, and } \\
\text { provision of new information }\end{array}$ & $\begin{array}{l}\text { Smart Seoul portal: 'Open Data Plaza', } \\
\text { 'Disclosure' } \\
\text { Amsterdam Smart City: 'Feedback' in 'Data } \\
\text { and Information' } \\
\text { Smart Nation Singapore }\end{array}$ & {$[7-9,54,76,89,92,94]$} \\
\hline $\begin{array}{l}\text { Data diversification and quality control by } \\
\text { directly uploading information generated by } \\
\text { citizens or companies to the portal and } \\
\text { displaying producers }\end{array}$ & $\begin{array}{l}\text { Smart Seoul portal: 'Open Data Plaza', } \\
\text { 'Disclosure' } \\
\text { Barcelona Digital City } \\
\text { Amsterdam Smart City } \\
\text { Smart Columbus } \\
\text { Smart Nation Singapore }\end{array}$ & [7-10,34,46,48,54,68,90,92-94] \\
\hline
\end{tabular}

\subsection{Participation}

In this regard, in the case of the Seoul Metropolitan Government, achieving a high level of public-private cooperation and providing citizen-oriented services are the two main strategies that are incorporated into the 'Smart Seoul' portal [97]. This is reflected in its content and layout; the main menu is divided into three axes that differentiate between smart city projects, provide spaces for interaction with citizens, and enable close working relationships with companies and entrepreneurs. The smart city projects that the Seoul Metropolitan Government is currently leading are grouped into various categories and disseminated on the portal; additionally, international cooperation activities have a large diffusion space within the portal $[95,96]$. However, sections such as 'Corporate Voice' and 'Citizens Voice', which are spaces intended to facilitate interaction and collect opinions, comments and suggestions from stakeholders are not being fully used. Very few comments have been registered in 'Corporate Voice' so far, and only a few initiatives have been posted in 'Citizens Voice'. Therefore, a constant feedback loop of ideas and opinions from stakeholders through the portal has not been realized. The 'Barcelona Digital City' portal's 'BIT Habitat-l lab' program focuses on the active participation of citizens and stakeholders in proposing ideas and solutions related to smart cities [90,91]. The city council held contests involving previously identified urban problems in the city [34]. Citizens, entrepreneurs and other stakeholders logged into the portal and suggested practical ideas to solve these problems. The owners of the best ideas were rewarded with small electronic devices, discount coupons, property tax deductions, etc. Likewise, the city council involved the winners in the design of the solution projects and financed the development of pilot experiments, simulations, prototypes or whatever was required to test the reliability of the proposals with the support of allied companies [34,90,91]. Similarly, the 'Smart Columbus' portal also offers programs that involve the direct participation of citizens who test new technologies related to transportation and mobility $[41,93]$. Other citizens can comment to show their agreement and provide ideas for the improvement of these projects. In the context of achieving a higher level of interaction with users, the proposed action is to encourage the participation of citizens, prompting them to generate ideas to urban problems or to improve projects through a series of incentives that can be awarded in open contests and competitions. In other words, it creates a space for the government to collaborate 
with citizens, and creates sustainable public value through the role of coordinator, the role of funder, and the role of regulator $[5,6,9,10,66,76]$. Citizens' interactions in competition processes must be done through the portal. For better transparency in the selection of winners, ideas can be voted by a specialized jury (where representatives from private companies and public institutions can participate). The winners can be rewarded with symbolic gifts such as electronic devices (cellphones, IPads, or watches), discount coupons (for services, store purchases, or cafes), or property tax deductions [93]. Additionally, for technology-specialized stakeholders, the proposed action is to develop an interactive space and refer to the experience provided by 'Smart Nation Singapore' [91]. In this portal, opportunities for capacity development and training through fellowships are offered, and specialized stakeholders are temporarily invited to contribute to engineering and technology solutions within ongoing projects.

The next proposed action takes the shared experiences in the 'Barcelona Digital City' portal as a reference; in this portal, challenges are conducted among technology entrepreneurs involving the development of apps that facilitate or add value to services provided by the portal [90]. Software development challenges could be promoted on the Smart Seoul portal. In these challenges, portal administrators must provide participants with the ability to link their programming codes to the portal's databases while complying with the required security and privacy requirements. The 'Smart City Center' could also be used as a physical space equipped with the technology needed to perform functional tests within the challenges. The winners could receive credit for the creation of the app in conjunction with the Seoul Metropolitan Government, and a massive dissemination campaign could be developed on the use of these new computer applications among citizens and other stakeholders. These proposed actions will help to drive and strengthen the city's smart governance strategies, achieving active participation and cooperation between the Seoul Metropolitan Government and its stakeholders and citizens. In addition, the strong involvement of society, entrepreneurs and companies in activities related to smart cities will be achieved. Therefore, stakeholders (public, private, academic, civic stakeholders) participate in capacity development and social and economic value creation. Additionally, shared ideas and solutions create new start-ups and jobs, and technology can spread widely and quickly through portals, contributing to creating new industrial competitiveness in cities $[5,7,9,14,25,46]$.

The 'Smart City Center' is a technologically equipped area where companies and entrepreneurs can conduct pilot tests and produce solutions that benefit urban development [97]. However, a rental payment is required for the use of these facilities, and these costs are sometimes an impediment for small businesses or entrepreneurs. Taking the 'Smart Nation Singapore' portal as a reference, an innovation laboratory equipped with technological tools and operated under the advice of experts could be provided, in which the owners of start-ups or entrepreneurs with an idea could experiment and develop solutions [94]. Likewise, the 'Barcelona Digital City' also offers services and laboratories designed for emerging digital entrepreneurs and attracts new talent in the field technology, ranking as the 4th European city in terms of start-up investment [34,91]. Therefore, another proposed action is to provide compensation or discounts based on the innovative results obtained by small companies or entrepreneurs and the ability of the proposed solutions to support future projects related to smart cities. This could promote the governance strategy of reducing the digital divide by making technology affordable to more users [13]. The 'Corporate Solution Zone' section aims to disseminate technology solutions [97]. Currently, 88 members of the company have registered their solutions, most of which relate to welfare, safety, and environmental issues. However, there is not a single comment or opinion in any of the descriptive files regarding the solutions; thus, there seems to be a lack of interest among other stakeholders in terms of reviewing, interacting with or inquiring about the solutions in this corporate promotion channel. In the portal of the 'Amsterdam Smart City', new technologies are widely disseminated through events promoted by the stakeholders that develop them and supported by the Municipality of Amsterdam [92]. Therefore, the 
proposed action in this case is to establish technology events in which the Seoul Metropolitan Government is in charge of inviting and bringing together allied companies, other stakeholders, and the general public to disseminate technological solutions and arouse interest for their widespread use [89]. The governance of the portal will be strengthened with the dissemination of technologies and the creativity produced by joint work with stakeholders $[48,64,65,67]$. The participation and involvement of citizens in the use of technology related to smart cities is also an important issue that the portal considers within its 'Citizens' axis, which offers spaces for the dissemination of technologies, the use of data, and training activities [97]. However, after a review of the 'Smart Citizen Lab' section, which is aimed at recruiting citizens who wish to participate in smart city programs, it is perceived that there has not been much interaction with them since only three events have been carried out in mid-2020 [97]. There are also no registered mentors, and there is very little participation in the 'community space'. The strategy of the Singapore government in the case of the 'Smart Nation Singapore' portal, in which the government promotes the 'Smart Nation Ambassador' program, is to train people regarding the concepts, objectives, scope, and development of smart cities. These individuals later disseminate this information to other citizens through roadshows, engagement activities and other events [94]. Therefore, the proposed action in this context is to encourage people's participation in selected groups based on the population and target audiences where each smart city program is focused $[4,54]$. Citizens can be classified based on age, education, or specialization. Active citizens can be invited to serve as volunteers supporting the dissemination of the concepts and technologies of smart cities, and they can be rewarded with certificates of participation or other small benefits. It is also important that smart city programs are selected in accordance with the ideas and opinions of citizens, which can be collected through the web, apps, social networks, surveys, etc. Citizens will be more interested if they are invited to participate from the beginning of programs that focus on solving urban problems that are of interest to them and that they currently face [7-9]. To ensure the participation of citizens both in the collection of ideas and opinions and in the execution of smart city programs, the inclusion of incentives such as small prizes (discount coupons, minimum tax reductions, etc.) can be considered. As a result, citizens feel satisfied when they experience a service that can obtain the information they want and solve problems, and the higher their satisfaction, the more they use the portal and participate actively [88]. The impact of these actions will be reflected in the strengthening of participatory and inclusive governance.

The section 'Digital Competency Enhancement Education' is a broad space that provides training opportunities to citizens on the use of new technologies available in smart cities [97]. No statistics are presented in the portal on the effectiveness of the development of these courses. Currently, the list of online courses is quite long (approximately 60 courses); however, each course only accepts a maximum of four students, and some of these courses do not reach their maximum capacity of participants. The case to consider in this context is the 'Barcelona Digital City', which has several programs focused on training people regarding technologies [90]. These programs are divided by age, social groups, the specializations of citizens, subjects of interest and level of difficulty. The courses are highly participatory in nature since many of them are also intended to provide citizens with technological capabilities for future jobs or new businesses. Therefore, the proposed action in this context is to disseminate training activities, identify target populations and send individuals invitations to participate in these activities through institutions and social groups. Small incentives and certificates that can be validated and included in people's resumes may also be offered to encourage participation. It is also recommended that courses aimed at social groups are divided according to age (for example, courses for children or young people) and that surveys be conducted on the training needs of citizens to promote the development of the most demanded courses. These measures provide tailored education to citizens, increasing satisfaction, narrowing the digital gap and increasing social integration and economic ripple effects $[5,88]$. Moreover, a general recommendation is to continue with 
the strategy of strengthening the connections between the Seoul Metropolitan Government and its stakeholders and citizens in the context of inclusive governance, in which all citizens, regardless of their social or economic status, age, sex or race, have the opportunity to participate in trainings, comment on projects and launch ideas in the market for the benefit of the city [54]. In the United States, less than $10 \%$ of the population is said to be active online content contributors [13]. A portal is a space where many citizens can participate at the same time regardless of time and place. However, the digital technology gap is becoming a significant obstacle to participation. In addition, advanced ICT technology has side effects that act as pressure on citizens. Therefore, various efforts to become a smart city are needed to not become a smart city without citizens [13,49]. Table 7 summarizes the strengthening plan for the participation mentioned above.

Table 7. Strengthening plan for participation.

\begin{tabular}{|c|c|c|}
\hline Proposed Action & Reference Portal & References \\
\hline $\begin{array}{l}\text { Realization of continuous feedback loop } \\
\text { for stakeholders' ideas and opinions: } \\
\text { hosting idea contests, awarding best } \\
\text { practices, funding the development of } \\
\text { pilot experiments \& prototypes, } \\
\text { providing professional competency } \\
\text { development and training }\end{array}$ & $\begin{array}{l}\text { Smart Seoul portal: 'Corporate Voice', } \\
\text { 'Citizens Voice' } \\
\text { Barcelona Digital City: 'BIT Habitat-lab' } \\
\text { Smart Columbus } \\
\text { Smart Nation Singapore }\end{array}$ & {$[4-6,9,10,34,41,76,90,91,94]$} \\
\hline $\begin{array}{l}\text { Providing innovation labs operated by } \\
\text { expert advice, experimenting with } \\
\text { solutions from start-ups, and supporting } \\
\text { start-up investments }\end{array}$ & $\begin{array}{l}\text { Smart Seoul portal: 'Smart City Center' } \\
\text { Smart Nation Singapore } \\
\text { Barcelona Digital City }\end{array}$ & {$[5,7,9,14,25,34,46,91,94,97]$} \\
\hline $\begin{array}{l}\text { Ads for spreading new technologies and } \\
\text { support for education/events of civic } \\
\text { groups: Provide education by } \\
\text { categorizing by age, social group, } \\
\text { expertise, topics of interest, and difficulty }\end{array}$ & $\begin{array}{l}\text { Smart Seoul portal: 'Corporate Solution } \\
\text { Zone', 'Digital Competency } \\
\text { Enhancement Education' } \\
\text { Barcelona Digital City } \\
\text { Amsterdam Smart City }\end{array}$ & {$[5,48,64,65,67,88,89,92,97]$} \\
\hline $\begin{array}{l}\text { Dissemination of information to other } \\
\text { citizens through education, participation } \\
\text { activities, and other events related to } \\
\text { smart city: awarding education } \\
\text { certificates, providing incentives }\end{array}$ & $\begin{array}{l}\text { Smart Seoul portal: 'Smart Citizen Lab', } \\
\text { 'community space' } \\
\text { Smart Nation Singapore: 'Smart Nation } \\
\text { Ambassador' }\end{array}$ & {$[4,7-9,54,88,94,97]$} \\
\hline
\end{tabular}

\subsection{Civil Petition Service}

In the 'Smart Seoul' portal, the civil petition service is often used by citizens through the hyperlinked menu option 'Response Station' [97]. This portal encompasses all the steps necessary for citizens to submit civil petitions, complaints and requests about the administrative services offered by the Seoul Metropolitan Government and the urban problems that they are currently facing. The process to make these petitions is very detailed and secure since a citizen must register and log in to fill out a request. Routine administrative procedures where citizens interact with the Seoul Metropolitan Government, such as paying property taxes and registering new properties, are not included in the portal. However, they are included in other administrative portals of the Seoul Metropolitan Government. The proposed action on this issue is to clearly link the 'Response Station' portal with the administrative portal of the Metropolitan Government of Seoul, in the same way as, for example, the 'Barcelona Digital City' portal $[90,97]$. In this portal, the main menu links to the 'Procedures' portal, which groups all the relevant administrative tasks within a virtual service window. This helps citizens directly access the use of the facilities provided by the virtual office for administrative procedures and helps them avoid carrying them out in person. Smart city portals enable direct and two-sided links through optimization of communication, improving citizen-centered administrative services and quality of public 
services [9,54]. In addition, it is possible to receive prompt and accurate services in an ICT environment that can be accessed regardless of time and place, increasing the satisfaction of citizens and thus active participation [71,88]. An additional proposed action is to expand the scope of the portal by adding an English version, which has been done, for example, in the 'Barcelona Digital City' portal; this portal displays information in English in addition to the official languages of Spain [90]. English is an inclusive language used by resident and nonresident foreigners who do not yet understand the Korean language but who could also take advantage of the facilities offered by the Smart Seoul portal and take part in its participatory and collaborative governance. As described above, measures to improve governance for information disclosure, participation, and citizen services were proposed. Ultimately, the most significant purpose the Seoul Portal pursues through the Smart City Project is citizen participation and cooperation [1,2]. In terms of introducing cutting-edge ICT technology and strengthening urban competitiveness, Seoul achieved outstanding achievements [2]. However, implementation of governance based on citizen participation is still insufficient. It is necessary to actively provide a space for citizens to freely access and express their voices by eliminating their reluctance to high-tech digital technology. The government should also take active measures to listen to citizens' opinions, reflect policies, and listen to the digitally underprivileged voices $[13,49]$. If these measures are successfully implemented, a citizen-centered smart city will be completed. Table 8 summarizes the strengthening plan for the civil petition service mentioned above.

Table 8. Strengthening plan for civil petition service.

\begin{tabular}{lll}
\hline \multicolumn{1}{c}{ Proposed Action } & \multicolumn{1}{c}{ Reference Portal } & References \\
\hline $\begin{array}{l}\text { By clearly connecting the 'Response Station' portal } \\
\text { and the administrative portal of Seoul City, }\end{array}$ & \multicolumn{1}{c}{ Smart Seoul portal: 'Response Station' } & {$[9,54,71,88,90,97]$} \\
$\begin{array}{l}\text { interactive services for general administration, } \\
\text { protection of personal privacy, and multi-language } \\
\text { support including English }\end{array}$ & \begin{tabular}{l} 
Barcelona Digital City \\
\hline
\end{tabular} & \\
\hline
\end{tabular}

\section{Conclusions}

In this study, we proposed a strengthening plan for the 'Smart Seoul' portal, analyzing its content and roles through a set of evaluation criteria based on governance strategies. We selected and evaluated the main features and roles of four representative smart city portals belonging to Barcelona, Amsterdam, Columbus, and Singapore. The analyzed features of each portal were classified based on certain governance strategies, and the key features were obtained and included in the evaluation criteria model. This evaluation criteria model was used to assess the structure and content of the 'Smart Seoul' portal. In this way, a strengthening plan was proposed, which included a set of actions designed to improve the usefulness and scope of the portal and to contribute to the fulfillment of its objectives related to information disclosure, stakeholder participation and civil services for citizens.

First, after analyzing the topics related to information disclosure, the proposed measures were presented: add GIS viewers to and include GIS-formatted statistical data in the 'Open Data Plaza' and 'Disclosure' portals, which will improve users' options in terms of searching, disclosing, and analyzing the spatial distribution of data based on geographic locations that are of interest to citizens or stakeholders $[46,47,97]$. Obtain feedback by deploying specific surveys to registered citizens about their level of satisfaction with the design and use of the tools and search methods of the portals and design a plan to improve these methods [46-49,92]. Further promote citizenship training activities, organizing them according to associations or social groups so that people can learn about the proper roles of current technologies and the services that can be provided through the 'Smart Seoul' portal and related technologies. Through these actions, the relevant governance strategies related to data accessibility can be strengthened by offering citizen-friendly portals facilitating the search and disclosure of data. Cooperative and participatory governance is also 
strengthened, since citizens know more about the information provided to them and may also propose the creation of new databases that serve to satisfy common needs $[13,49,90]$. The disclosure of information through the 'Smart Seoul' portal can ensure the transparency of Seoul's administration and create an environment in which citizens actively participate in urban problem solving and decision making. In addition, as an open government portal, it can create public interest by improving the usability and availability of public data [46]. However, a legal system should also be prepared in consideration of the privacy issues that may arise from the provision and sharing of information, as well as the ethical issues and conflicts of interest that may arise during the process of analyzing and using this information $[46,48]$. As a result, smart city portals have a great advantage in creating sustainable public interests by realizing transparency and citizen-centered information usefulness through rapid and extensive information disclosure. Compared to face-to-face information disclosure, its usefulness and visibility are very excellent. In addition, information can be accessed anywhere and anytime, which can greatly improve the quality of public services [7-10,54,65,89].

Second, regarding citizen and stakeholder participation in portal activities, we presented a set of proposed actions: Encourage citizens and other stakeholders to participate by offering ideas and solutions to urban problems or improving projects through various incentives that could be given as prizes in open contests and competitions [34,93]. Moreover, fellowships should be offered, in which specialized stakeholders are temporarily invited to contribute to creating engineering and technology solutions within ongoing projects. Facilitate challenges for technology entrepreneurs related to the development of apps that facilitate or add value to services provided by the portal. Provide compensation or discounts to small companies or entrepreneurs who use the 'Smart City Center', depending on their innovative results and the ability of their solutions to support future projects related to smart cities. Host more technology events in which the Seoul Metropolitan Government is in charge of inviting and bringing together allied companies, other stakeholders, and the general public to disseminate technological solutions and arouse interest for their widespread use. Encourage the participation of active citizens as volunteers supporting the dissemination of concepts and technologies related to smart cities, providing them with certificates of participation or other small benefits in exchange. Disseminate training activities, identifying target populations, and inviting them to participate through institutions and social groups [23]. The impact of these actions will be reflected in the strengthening of participatory, collaborative, and inclusive governance, the achievement of active participation, and cooperation between the government and its stakeholders and citizens $[24,46,49]$. In addition, the strong involvement of society, entrepreneurs and companies in activities related to smart cities will be realized. These actions will also have a great effect on reducing the digital divide and will maximize social inclusion in the context of effective network governance. Citizen participation and collaboration through the 'Smart Seoul' portal will allow citizens to lead smart city policies and become directly involved in urban problems. Furthermore, this will allow citizens to play an active role in accordance with the spirit of shared responsibility [47-49,53]. One of the most important goals of Seoul's smart city project is citizen participation and cooperation [2]. Compared to developing new ICT technologies and strengthening urban competitiveness, citizen participation was insufficient. Therefore, it is necessary to promote sustainable improvement measures step by step to promote citizen participation and cooperation by establishing a platform and opening a portal. Citizens should be at the center and not be alienated by being overwhelmed by intelligent ICT technology, and improvement measures should be reinforced so that the voice of the citizens can be reflected in the policy [56-58]. As a result, the government must find a way to actively induce citizens' participation through smart city portals and share roles between the government and citizens. The portal allows many citizens to participate at the same time, present their opinions, and devise cooperation plans. In other words, the decision-making process and method are changing. Citizens' participa- 
tion and decision-making through portals can enhance understanding and satisfaction of government policies, resulting in sustainable participation $[4-6,9,10,25,76]$.

Third, regarding civil petition service, the proposed action is to clearly and directly connect the web link between the 'Response Station' portal and the administrative portal of the Seoul Metropolitan Government to help citizens easily access. Additionally, it helps citizens use the facilities provided by virtual offices [2]. An additional proposed action is to expand the scope of the portal by adding an English version, as English is an inclusive language used by resident and nonresident foreigners who do not yet understand the Korean language but who could also take advantage of the facilities offered by the 'Smart Seoul' portal. As a result, civil service through portals must continuously seek out citizencentered service methods. It is necessary to continuously improve the inconvenience of citizens by providing feedback on surveys or petitions, and create a two-way channel to communicate with the citizens $[9,54,71,88]$.

As described above, by reviewing literature and analyzing the features of four smart city portals, a plan to reinforce governance of the Seoul portal was suggested. Currently, many smart city portals are being built and operated around the world, but there are no standardized business rules for governance functions and operations that portals should have. In that respect, we hope that the results of this study will be used as an important guideline to consider in designing and operating a smart city portal. Lastly, it is the future research direction on the relationship between the smart city project and the portal. The function and role of the portal in the smart city project is also unclear. Many scholars predict that the advantages of the portal will greatly contribute to smart city governance. That is, advanced ICT technology already dominates urban spaces, and the way and quality of citizens' lives are influenced by their power. Nevertheless, in-depth research on how online collaboration and smart city governance affect the quality of life for citizens in offline is still lacking. Therefore, attention should be paid to how non-face-to-face participation and collaboration can change the way of life of citizens. In-depth research on this should be continued in the future.

Funding: This work is supported by the Korea Agency for Infrastructure Technology Advancement (KAIA) grant funded by the Ministry of Land, Infrastructure and Transport (Grant 21DEAP-B158906-02).

Institutional Review Board Statement: Not applicable.

Informed Consent Statement: Not applicable.

Data Availability Statement: Data sharing not applicable.

Conflicts of Interest: The author declares no conflict of interest.

\section{References}

1. Seoul E-Government. Seoul Metropolitan Government, Korea. Available online: http://susa.or.kr/sites/default/files/resources/ Seoul\%20e-Government\%20\%28English\%29.pdf (accessed on 3 February 2021).

2. Seoul Metropolitan Government. Seoul Smart City Platform White Paper. Available online: https://publicadministration. un.org/Unpsa/Portals/0/UNPSA_Submitted_Docs/2019/4f4c5d55-C9e6-4e61-Bc76-F8fc93bfdcdf/2020\%20UNPSA_ SCPM_Whitepaper_27112019_011429_0bc8129d-6963-46a7-A4a2-0d29c203ca4c.Pdf?Ver=1441-03-30-011430-090 (accessed on 8 December 2020).

3. Giffinger, R.; Fertner, C.; Kalasek, R.; Pichler-Milanović, N. Smart Cities-Ranking of European Medium-Sized Cities. Final Report. The Centre of Regional Science. Vienna University of Technology. 2007. Available online: https://www.researchgate.net/ publication/261367640_smart_cities_-_ranking_of_european_medium-sized_cities (accessed on 8 November 2019).

4. Bolívar, M.P.R.; Meijer, A.J. Smart Governance: Using a Literature Review and Empirical Analysis to Build a Research Model. Soc. Sci. Comput. Rev. 2016, 34, 673-692. [CrossRef]

5. Dameri, R.P.; Benevolo, C. Governing Smart Cities: An Empirical Analysis. Soc. Sci. Comput. Rev. 2016, 34, 693-707. [CrossRef]

6. Chatfield, A.T.; Reddick, C.G. Smart City Implementation Through Shared Vision of Social Innovation for Environmental Sustainability: A Case Study of Kitakyushu, Japan. Soc. Sci. Comput. Rev. 2016, 34, 757-773. [CrossRef]

7. Ruhlandt, R.W.S. The Governance of Smart Cities: A Systematic Literature Review. Cities 2018, 81, 1-23. [CrossRef]

8. Dameri, R.P.; Ricciardi, F. Smart City Intellectual Capital: An Emerging View of Territorial Systems Innovation Management. J. Intellect. Cap. 2015, 16, 860-887. [CrossRef] 
9. Pereira, G.V.; Parycek, P.; Falco, E.; Kleinhans, R. Smart Governance in the Context of Smart Cities: A Literature Review. Inf. Polity 2018, 23, 143-162. [CrossRef]

10. Estevez, E.; Janowski, T. Electronic Governance for Sustainable Development-Conceptual Framework and State of Research. Gov. Inf. Q. 2013, 30, S94-S109. [CrossRef]

11. Ansell, C.; Gash, A. Collaborative Platforms as a Governance Strategy. J. Public Adm. Res. Theory 2018, 28, 16-32. [CrossRef]

12. O'Reilly, T. Government as a Platform. Innovations 2010, 6, 13-40. Available online: https://www.mitpressjournals.org/doi/pdf/ 10.1162/INOV_a_00056 (accessed on 10 November 2019). [CrossRef]

13. Linders, D. From E-Government to We-Government: Defining a Typology for Citizen Coproduction in the Age of Social Media. Gov. Inf. Q. 2012, 29, 446-454. [CrossRef]

14. Neumann, O.; Matt, C.; Hitz-Gamper, B.S.; Schmidthuber, L.; Stürmer, M. Joining Forces for Public Value Creation? Exploring Collaborative Innovation in Smart City Initiatives. Gov. Inf. Q. 2019, 36, 101411. [CrossRef]

15. Wijnhoven, F.; Ehrenhard, M.; Kuhn, J. Open Government Objectives and Participation Motivations. Gov. Inf. Q. 2015, 32, 30-42. [CrossRef]

16. Sørensen, E. Metagovernance: The Changing Role of Politicians in Processes of Democratic Governance. Am. Rev. Public Adm. 2006, 36, 98-114. [CrossRef]

17. Powell, W. Neither Market nor Hierarchy: Network Forms of Organization. Res. Organ. Behav. 1990, 12, 295-336. Available online: https:/ / www.researchgate.net/publication/301840604_Neither_Market_Nor_Hierarchy_Network_Forms_of_Organization (accessed on 8 November 2019).

18. Provan, K.G.; Kenis, P. Modes of Network Governance: Structure, Management, and Effectiveness. J. Public Adm. Res. Theory 2007, 18, 229-252. [CrossRef]

19. Parker, G.; Van Alstyne, M.; Choudary, S. Platform Revolution: How Networked Markets Are Transforming the Economy and How to Make them Work for You; WW Norton \& Company: London, UK, 2016.

20. Accenture. Government as a Platform. 2018. Available online: https://www.accenture.com/us-en/insights/public-service/ government-as-a-platform (accessed on 10 November 2019).

21. Millard, J. Open Governance Systems: Doing More with More. Gov. Inf. Q. 2018, 35, S77-S87. [CrossRef]

22. Gorwa, R. What Is Platform Governance? Inf. Commun. Soc. 2019, 22, 854-871. [CrossRef]

23. Anttiroiko, A.-V. City-as-a-Platform: The Rise of Participatory Innovation Platforms in Finnish Cities. Sustainability $2016,8,922$. [CrossRef]

24. Eggers, W.D.; Skowron, J. Forces of Change: Smart Cities; Deloitte: London, UK, 2018. Available online: https://www2.deloitte $\mathrm{com} /$ content/dam/insights/us/articles/4421_Forces-of-change-Smart-cities/DI_Forces-of-change-Smart-cities.pdf (accessed on 15 January 2020).

25. Bifulco, F.; Tregua, M.; Amitrano, C.C.; D’Auria, A. ICT and Sustainability in Smart Cities Management. Int. J. Public Sect. Manag. 2016, 29, 132-147. [CrossRef]

26. Stoker, G. Governance as Theory: Five Propositions. Int. Soc. Sci. J. 2018, 68, 15-24. [CrossRef]

27. Korean Government. Korean New Deal-Accelerating the Spread of Smart City Integrated Platform. Available online: https: / / www.molit.go.kr/USR/NEWS/m_71/dtl.jsp?lcmspage=1\&id=95084183 (accessed on 15 November 2020).

28. Lee, S. Planning Research of Smart Seoul Cooperation Platform for Promotion of Public-Private Cooperation; Seoul Digital Foundation: Seoul, Korea, 2019. Available online: https://smart.seoul.go.kr/board/41/1218/board_view.do (accessed on 15 June 2020).

29. Lee, B.H. ASEAN Smart City Network (ASCN): Pilot Project and Smart Solution. KRIHS SPECIAL REPORT 50. 2019. Available online: https:/ /library.krihs.re.kr/dl_image2/IMG/07/000000030229/SERVICE/000000030229_01.PDF (accessed on 2 September 2020).

30. Pellicer, S.; Santa, G.; Bleda, A.L.; Maestre, R.; Jara, A.J.; Skarmeta, A.G. A Global Perspective of Smart Cities: A Survey. In Proceedings of the 2013 Seventh International Conference on Innovative Mobile and Internet Services in Ubiquitous Computing, Taichung, Taiwan, 3-5 July 2013; pp. 439-444. [CrossRef]

31. Hayat, P. Smart Cities: A Global Perspective. India Q. 2016, 72, 177-191. [CrossRef]

32. European Commission. Available online: https://ec.europa.eu/regional_policy/en/policy/what/glossary/e/europe-2020 -strategy (accessed on 6 August 2020).

33. The White House-President Barack Obama. Available online: https://obamawhitehouse.archives.gov/the-press-office/2015/09/ 14/fact-sheet-administration-announces-new-smart-cities-initiative-help (accessed on 24 February 2020).

34. Ferrer, J.-R. Barcelona's Smart City Vision: An Opportunity for Transformation. J. Field Actions 2017, 16, 70-75. Available online: http:/ /journals.openedition.org/factsreports / 4367 (accessed on 5 January 2021).

35. Philips Lighting. Smart Cites World: Understanding the Challenges and Opportunities of Smart Cities, 2017. Available online: https://smartcitiesworld.net/AcuCustom/Sitename/DAM/012/Understanding_the_Challenges_and_Opportunities_ of_Smart_Citi.pdf (accessed on 9 April 2021).

36. City of Amsterdam. Amsterdam European Capital of Innovations 2016. Available online: https://www.amsterdam.nl/wonenleefomgeving/innovatie/european-capital (accessed on 9 April 2021). 
37. Amsterdam Smart City. Available online: https://amsterdamsmartcity.com/updates/news/amsterdam-wins-prestigious-awardfor-circular-econ (accessed on 10 April 2021).

38. Amsterdam Smart City. Amsterdam Smart City Awarded for Best Emerging Technologies. 2017. Available online: https: //amsterdamsmartcity.com/updates/news/amsterdam-smart-city-awarded-for-best-emerging-tec (accessed on 6 April 2021).

39. IESE Business School, University of Navarra. IESE Cities in Motion Index. 2019. Available online: https://media.iese.edu/ research/pdfs/ST-0509-E.pdf (accessed on 6 April 2021).

40. Ginther, A.J. Smart City, the City of Columbus. Available online: https://www.eenews.net/assets/2016/03/31/document_pm_ 02.pdf (accessed on 7 April 2021).

41. Smart Columbus. Data Management Plan. Available online: https://www.smartcolumbusos.com/images/2020/PDF/SCC-EDataManagementPlan-Update-v1.pdf (accessed on 8 January 2021).

42. Estevez, E.; Lopes, N.; Janowski, T. Smart Sustainable Cities. United Nations University \& International Development Research Center. 2015. Available online: https:/ / collections.unu.edu/eserv/UNU:5825/Smart_Sustainable_Cities_v2final.pdf (accessed on 12 April 2021).

43. Institute of Digital Government at Waseda University. The 15th WASEDA International Digital Government Rankings Report. September 2020. Available online: https://idg-waseda.jp/pdf/WASEDA_Digital_Government_Ranking_2019_2020.pdf (accessed on 4 April 2021).

44. Eden Strategy Institute. Top 50 Smart City Governments. 2021. Available online: https:/ /www.thesmartcityjournal.com/en/ cities / the-top-50-smart-city-governments-in-2021 (accessed on 6 April 2021).

45. Institute for Management Development. "Smart City Index", 2020. Available online: https://www.imd.org/smart-cityobservatory/smart-city-index/ (accessed on 1 April 2021).

46. Hitz-Gamper, B.S.; Neumann, O.; Stürmer, M. Balancing Control, Usability and Visibility of Linked Open Government Data to Create Public Value. Int. J. Public Sect. Manag. 2019, 32, 451-466. [CrossRef]

47. Cardullo, P.; Kitchin, R. Being a 'Citizen' in the Smart City: Up and down the Scaffold of Smart Citizen Participation in Dublin, Ireland. GeoJournal 2019, 84, 1-13. [CrossRef]

48. Open Cities. Open Data: Collaborative Cities in the Information Era; Hawken, S., Han, H., Pettit, C., Eds.; Springer: Singapore, 2020; ISBN 9789811366048.

49. Vanolo, A. Is there anybody out there? The place and role of citizens in tomorrow's smart cities. Futures 2016, 82, 26-36. [CrossRef]

50. Türke, R.-E. Sustainable Governance. In Systemic Management for Intelligent Organizations; Grösser, S.N., Zeier, R., Eds.; Springer: Berlin/Heidelberg, Germany, 2012; pp. 237-247. ISBN 978-3-642-29243-9.

51. Rhodes, R.A.W. The New Governance: Governing without Government. Political Stud. 1996, 44, 652-667. [CrossRef]

52. SAGE Books. Governing as Governance. Available online: https://sk.sagepub.com/books/governing-as-governance (accessed on 24 April 2021).

53. Provan, K.G.; Milward, H.B. A Preliminary Theory of Interorganizational Network Effectiveness: A Comparative Study of Four Community Mental Health Systems. Adm. Sci. Q. 1995, 40, 1. [CrossRef]

54. Marek, L.; Campbell, M.; Bui, L. Shaking for Innovation: The (Re)Building of a (Smart) City in a Post Disaster Environment. Cities 2017, 63, 41-50. [CrossRef]

55. Meuleman, L. Metagovernance for Sustainability-A Framework for Implementing the Sustainable Development Goals; Routledge: Oxfordshire, UK, 2020.

56. Alhusban, M. The Practicality of Public Service Integration. Electron. J. e-Gov. 2015, 13, 94-109.

57. Kooiman, J.; Jentoft, S. Meta-Governance: Values, Norms and Principles, and the Making of Hard Choices. Public Adm. 2009, 87, 818-836. [CrossRef]

58. Georgetown University Press. Collaborative Governance Regimes; Georgetown University Press: Washington, DC, USA, 2015. Available online: http:/ / press.georgetown.edu/book/georgetown/collaborative-governance-regimes (accessed on 24 April 2021).

59. Sundberg, L. Risk and Decision in Collaborative E-Government: An Objectives-Oriented Approach. Electron. J. e-Gov. 2016, $14,35-46$.

60. Pierre, J.; Peters, B.G. Governance, Politics and the State, 2000th ed.; Palgrave Macmillan: New York, NY, USA, 2000; ISBN 978-0-312-23177-4.

61. Raunio, M.; Nordling, N.; Kautonen, M. Open Innovation Platforms as a Knowledge Triangle Policy Tool—Evidence from Finland. форсайт 2018, 12, 62-76. [CrossRef]

62. Meijer, A.J.; Curtin, D.; Hillebrandt, M. Open Government: Connecting Vision and Voice. Int. Rev. Adm. Sci. 2012, 78, 10-29. [CrossRef]

63. Goldsmith, S.; Eggers, W.D. Governing by Network: The New Shape of the Public Sector; Brookings Institution Press: Washington, DC, USA, 2004.

64. Increasing Collaboration and Participation in Smart City Governance: A Cross-Case Analysis of Smart City Initiatives. Available online: https: / / www.tandfonline.com/doi/full/10.1080/02681102.2017.1353946 (accessed on 15 May 2021).

65. Zissis, D.; Lekkas, D. Securing E-Government and e-Voting with an Open Cloud Computing Architecture. Gov. Inf. Q. 2011, 28, 239-251. [CrossRef] 
66. Mapping Dimensions of Governance in Smart Cities. In Proceedings of the 17th International Digital Government Research Conference on Digital Government Research, Shanghai, China, 8-10 June 2016. Available online: https://dl.acm.org/doi/abs/10 $.1145 / 2912160.2912176$ (accessed on 15 May 2021).

67. Han, H.; Hawken, S. Introduction: Innovation and Identity in next-Generation Smart Cities. City Cult. Soc. 2018, 12, 1-4. [CrossRef]

68. Bifulco, F.; Tregua, M.; Amitrano, C.C. Co-Governing Smart Cities Through Living Labs. Top Evidences From EU. Transylv. Rev. Adm. Sci. 2017, 13, 21-37. [CrossRef]

69. Thornton, B. City-as-a-Platform: Applying Platform Thinking to Cities. Available online: https://platformthinkinglabs.com/ materials/city-as-a-platform-applying-platform-thinking-to-cities/ (accessed on 23 November 2020).

70. Martin, C.J.; Upham, P.; Klapper, R. Democratising Platform Governance in the Sharing Economy: An Analytical Framework and Initial Empirical Insights. J. Clean. Prod. 2017, 166, 1395-1406. [CrossRef]

71. Hung, S.-Y.; Chang, C.-M.; Kuo, S.-R. User Acceptance of Mobile E-Government Services: An Empirical Study. Gov. Inf. Q. 2013, 30, 33-44. [CrossRef]

72. Freeman, R.J.; Loo, P. Web 2.0 and E-Government at the Municipal Level. In Proceedings of the Web 2.0 and E-Government at the Municipal Level, St. John's, NL, Canada,, 25-27 August 2009; 2009; pp. 70-78.

73. Deakins, E.; Dillon, S.M. E-government in New Zealand: The Local Authority Perspective. Int. J. Public Sect. Manag. 2002, 15, 375-398. [CrossRef]

74. Jakob, N. Usability Engineering; Elsevier: Amsterdam, The Netherlands, 1993. Available online: https://www.nngroup.com/ books/usability-engineering/ (accessed on 24 April 2021).

75. Muhammad, A.H.; Siddique, A.; Youssef, A.E.; Saleem, K.; Shahzad, B.; Akram, A.; Al-Thnian, A.-B.S. A Hierarchical Model to Evaluate the Quality of Web-Based E-Learning Systems. Sustainability. 2020, 12, 4071. [CrossRef]

76. Khalil, O.E.M. E-Government Readiness: Does National Culture Matter? Gov. Inf. Q. 2011, 28, 388-399. [CrossRef]

77. Nielsen, J. 10 Usability Heuristics for User Interface Design. Available online: https: / www.designprinciplesftw.com/collections / 10-usability-heuristics-for-user-interface-design (accessed on 15 February 2021).

78. Introna, L.; Hayes, N.; Petrakaki, D. The Working Out of Modernization in the Public Sector: The Case of an E-Government Initiative in Greece. Int. J. Public Adm. 2009, 33, 11-25. [CrossRef]

79. Alshehri, M.; Drew, S. A Comprehensive Analysis of E-Government Services Adoption in Saudi Arabia: Obstacles and Challenges. Int. J. Adv. Comput. Sci. Appl. 2012, 3. [CrossRef]

80. Janssen, M.; Estevez, E. Lean Government and Platform-Based Governance-Doing More with Less. Gov. Inf. Q. 2013, 30, S1-S8. [CrossRef]

81. Harrison, T.M.; Guerrero, S.; Burke, G.B.; Cook, M. Open Government and e-Government: Democratic Challenges from a Public Value Perspective. In Proceedings of the 12th Annual International Conference on Digital Government Research, College Park, MD, USA, 12-15 June 2011; pp. 245-253. Available online: https:/ / ctg.albany.edu/media/pubs/pdfs /dgo2011_opengov.pdf (accessed on 21 February 2020).

82. Jamal, M.A.; Shanab, E.A. The Influence of Open Government on E-Government Website: The Case of Jordan. Int. J. Electron. Gov. 2016, 8, 159. [CrossRef]

83. Open Government. United Cities and Local Governments. Available online: https://opengov.uclg.org/en/open-government (accessed on 11 February 2020).

84. What Is Open Government and Why Is It Important? Available online: https://www.opendatasoft.com/blog/an-essentialintroduction-to-open-government (accessed on 24 February 2020).

85. Caiado, R.G.G.; Carocha, D.M.; Goulart, A.K.; Tortorella, G.L. Critical Success Factors-Based Taxonomy for Lean Public Management: A Systematic Review. Production 2020,30, e20200030. Available online: https://www.redalyc.org/jatsRepo/3967/3967620 $77033 / \mathrm{html} /$ index.html (accessed on 9 January 2021). [CrossRef]

86. Lukrafka, T.O.; Silva, D.S.; Echeveste, M. A Geographic Picture of Lean Adoption in the Public Sector: Cases, Approaches, and a Refreshed Agenda. Eur. Manag. J. 2020, 38, 506-517. [CrossRef]

87. Lins, M.G.; Zotes, L.P.; Caiado, R. Critical Factors for Lean and Innovation in Services: From a Systematic Review to an Empirical Investigation. Total Qual. Manag. Bus. Excell. 2021, 32, 606-631. [CrossRef]

88. Reddick, C.G.; Roy, J. Business Perceptions and Satisfaction with E-Government: Findings from a Canadian Survey. Gov. Inf. Q. 2013, 30, 1-9. [CrossRef]

89. Anthopoulos, L.G.; Reddick, C.G. Understanding Electronic Government Research and Smart City: A Framework and Empirical Evidence. Inf. Polity 2016, 21, 99-117. [CrossRef]

90. Info Barcelona-Smart City. Available online: https://www.barcelona.cat/infobarcelona/en/tema/smart-city (accessed on 15 November 2020).

91. Bee Smart City. Smart City Portrait: Barcelona. Available online: https:/ /hub.beesmart.city/city-portraits/smart-city-portraitbarcelona (accessed on 2 January 2021).

92. Amsterdam Smart. Available online: https://amsterdamsmartcity.com (accessed on 15 November 2020).

93. Smart Columbus. Available online: https://www.smartcolumbusos.com/ (accessed on 15 November 2020).

94. Smart Nation Singapore. Available online: https://www.smartnation.gov.sg/ (accessed on 15 November 2020). 
95. How Is Seoul, Korea Transforming into a Smart City? Available online: https://blogs.worldbank.org/sustainablecities/howseoul-korea-transforming-smart-city (accessed on 6 December 2020).

96. City Focus: Seoul-Digital City. Available online: https://realassets.ipe.com/city-focus-seoul-digital-city/10034657.article (accessed on 6 December 2020).

97. Smart Seoul Portal. Available online: https://smart.seoul.go.kr/index.do (accessed on 8 December 2020). 